Roger Williams University

DOCS@RWU

$11-2019$

\title{
Rescinding Inclusion in the Administrative State: Adjudicating DACA, the Census, and the Military's Transgender Policy
}

Peter Margulies

Roger Williams University School of Law, pmargulies@rwu.edu

Follow this and additional works at: https://docs.rwu.edu/law_fac_fs

Part of the Administrative Law Commons, Immigration Law Commons, Law and Gender Commons, Military, War, and Peace Commons, and the President/Executive Department Commons

\section{Recommended Citation}

Peter Margulies, Rescinding Inclusion in the Administrative State: Adjudicating DACA, the Census, and the Military's Transgender Policy, 71 Fla. L. Rev. 1429 (2019).

This Article is brought to you for free and open access by the Law Faculty Scholarship at DOCS@RWU. It has been accepted for inclusion in Law Faculty Scholarship by an authorized administrator of DOCS@RWU. For more information, please contact mwu@rwu.edu. 


\section{HEINONLINE}

DATE DOWNLOADED: Tue Apr 7 11:01:45 2020

SOURCE: Content Downloaded from HeinOnline

Citations:

Bluebook 20th ed.

Peter Margulies, Rescinding Inclusion in the Administrative State: Adjudicating DACA, the Census, and the Military's Transgender Policy, 71 Fla. L. Rev. 1429 (2019).

ALWD 6th ed.

Peter Margulies, Rescinding Inclusion in the Administrative State: Adjudicating DACA, the Census, and the Military's Transgender Policy, 71 Fla. L. Rev. 1429 (2019).

APA 6th ed.

Margulies, P. (2019). Rescinding inclusion in the administrative state: Adjudicating daca, the census, and the military's transgender policy. Florida Law Review, 71(6), 1429-1480.

Chicago 7th ed.

Peter Margulies, "Rescinding Inclusion in the Administrative State: Adjudicating

DACA, the Census, and the Military's Transgender Policy," Florida Law Review 71, no.

6 (November 2019): 1429-1480

McGill Guide 9th ed.

Peter Margulies, "Rescinding Inclusion in the Administrative State: Adjudicating

DACA, the Census, and the Military's Transgender Policy" (2019) 71:6 Fla L Rev 1429.

MLA 8th ed.

Margulies, Peter. "Rescinding Inclusion in the Administrative State: Adjudicating

DACA, the Census, and the Military's Transgender Policy." Florida Law Review, vol.

71, no. 6, November 2019, p. 1429-1480. HeinOnline.

OSCOLA 4th ed.

Peter Margulies, 'Rescinding Inclusion in the Administrative State: Adjudicating

DACA, the Census, and the Military's Transgender Policy' (2019) 71 Fla L Rev 1429

Provided by:

Roger Williams University School of Law Library

-- Your use of this HeinOnline PDF indicates your acceptance of HeinOnline's Terms and Conditions of the license agreement available at https://heinonline.org/HOL/License

-- The search text of this PDF is generated from uncorrected OCR text.

-- To obtain permission to use this article beyond the scope of your license, please use: Copyright Information 
RESCINDING INCLUSION IN THE ADMINISTRATIVE STATE: ADJUDICATING DACA, THE CENSUS, AND THE MILITARY'S TRANSGENDER POLICY

\title{
Peter Margulies ${ }^{*}$
}

\begin{abstract}
The rescission of programs, policies, and practices by an incoming administration often raises legal questions. However, answers are harder to find. That is the case with the whirlwind of rollbacks proposed and implemented by the Trump administration in areas from transgender persons in the military to asking a citizenship question on the census and terminating Deferred Action for Childhood Arrivals (DACA) and Temporary Protected Status (TPS). This Article provides a lens for assessing the legality of these seemingly precipitous moves. Viewing these abrupt paradigm shifts as threshold rescissions clarifies the legal landscape. Threshold measures govern baseline access to goods and institutions, including military service, political representation, and living and working legally in the United States. Under current case law, changes to many threshold measures would be purely discretionary, subject to very relaxed judicial review or no review at all. This Article suggests that reliance interests in threshold measures warrant a more robust judicial role in assessing the means-ends fit of proposed rescissions, equivalent to intermediate scrutiny in equal protection cases. The prior factfinding and legislative support invested in reforms slated for rescission further justify more probing judicial inquiry. The approach urged here also supplies a welcome normative dimension to scholarly discussions of administrative constitutionalism. Scholars have highlighted agency readings to expand individual rights. President Obama's administration did this in the context of ending the military's ban on accession and retention of transgender service members. The Trump administration now wishes to partially roll back that inclusive measure. Current officials' approach to transgender accession and retention reveals that administrative constitutionalism is contested terrain: one administration's salutary expansion of individual rights strikes a new administration as defaulting on responsibility, overreaching on power, and interfering with the rights of other parties. There may be common ground, including former Defense Secretary James Mattis's decision to grandfather in transgender service members who acted in reliance on the Obama administration's reform. However, the intermediate scrutiny applied here would invalidate most other components of the Defense Department's transgender rollback, and would require further process and explanation
\end{abstract}

* Professor of Law, Roger Williams University School of Law; B.A., Colgate University; J.D., Columbia Law School. I thank the expert reference librarians at Roger Williams Law School for their assistance. 
before upholding a citizenship question on the census or the termination of DACA and TPS. In addition, the approach taken here harmonizes with the United States Supreme Court's finding in the census citizenshipquestion case that the Commerce Department's reliance on Voting Rights Act enforcement was pretextual. Analyzing the means-ends fit of threshold rescissions promotes more effective deliberation about abrupt changes, while allowing a new administration to refine its rationale.

INTRODUCTION

I. AdMinistrative CONSTITUTIONALISM AND THRESHOLD RESCISSIONS

A. Administrative Constitutionalism and Individual Rights

B. The Role of the Courts in Assessing Threshold Rescissions

C. Threshold Rescission and the Importance of Means-Ends Scrutiny.

II. The Trump Administration's NeW RESTRICTIONS on Transgender Military Service: Of False STARTS AND GRANDFATHERED ORPHANS

A. Secretary Carter's Constitutionalist Vision 1452

1. Transgender Personnel Currently Serve in the Military....

2. Responsibility and Guidance in the Carter Policy

3. Taking Statistics Seriously: Low Base Rates for Transgender Personnel

B. The Mattis Policy's Constitutionalist Response 1456

1. The Mattis Policy's Partial Rollback

2. The Mattis Policy and Means-Ends Fit 1458

III. Tile Census Citizenship Question As A TIIRISIIOI,D RISSCISSION

A. Past Practice on Asking the Citizenship Question .......1461

B. The Citizenship Question and Means-Ends Fit 1463

IV. TIII: DACA AND TPS RI:SCISSIONS 1467

A. The Constitutionalist Origins of the DACA Program

B. The Structural Counter to Broad-Based Deferred Action

C. Rescinding Temporary Protected Status 1474 


\section{INTRODUCTION}

Rolling back Obama Administration measures has been a signature move of the Trump Administration. For example, the Trump Administration has sought to rescind grants of Deferred Action for Childhood Arrivals (DACA) and Temporary Protected Status (TPS), substantially reverse the Obama Administration's steps toward accession into the military of transgender individuals, ${ }^{2}$ and depart from longstanding practice by asking a question on the United States census about citizenship status. ${ }^{3}$ Judicial outcomes have been mixed thus far, with the United States Supreme Court upholding an injunction against the census citizenship question ${ }^{4}$ and granting a stay of lower court injunctions against the transgender rescission, ${ }^{5}$ and an appellate court ruling that challengers to the DACA rescission had stated an equal protection claim. ${ }^{6}$

1. See Letter from Jefferson B. Sessions III, Attorney Gen., U.S., to Elaine C. Duke, Acting Sec'y, U.S. Dep't of Homeland Sec. (Sept. 5, 2017), https://www.dhs.gov/sites/ default/files/publications/17_0904_DOJ_AG-letter-DACA.pdf [https://perma.cc/54MP-VN6V]; Memorandum from Kirstjen M. Nielsen, Sec'y, U.S. Dep't of Homeland Sec. (June 22, 2018), https://www.dhs.gov/sites/default/files/publications/18_0622_S1_Memorandum_DACA.pdf [https://perma.cc/A2WR-WW6J]; see also Ramos v. Nielsen, $33 \overline{6}$ F. Supp. 3d 1075, 1108-09 (N.D. Cal. 2018) (enjoining termination of TPS for Sudan, Haiti, El Salvador, and Nicaragua).

2. See Memorandum from Donald J. Trump, President of the U.S., to James N. Mattis, Sec'y of Def., U.S. Dep't of Def., and Jefferson B. Sessions III, U.S. Attorney Gen. (Mar. 23, 2018), https://partner-mco-archive.s3.amazonaws.com/client_files/1521897503.pdf [https:// perma.cc/CCD6-PUGD].

3. See Memorandum from Wilbur Ross, Sec'y, U.S. Dep't of Commerce, to Karen Dunn Kelley, Under Sec'y for Econ. Affairs, U.S. Dep't of Commerce (Mar. 26, 2018), https://www.documentcloud.org/documents/4426785-commerce2018-03-26-2.html [https:// perma.cc/HHH2-A6N3]. See generally New York v. U.S. Dep't of Commerce, 351 F. Supp. 3d 502 (S.D.N.Y.) (setting aside Secretary Ross's decision to add a citizenship question to the 2020 census as arbitrary and capricious), cert. granted, 139 S. Ct. 953 (2019).

4. See Dep't of Commerce v. New York, 139 S. Ct. 2551, 2576 (2019).

5. See Orders of the Court - Term Year 2018: Order List of January 22, 2019, SUPREME Cr. OF THE U.S. (Jan. 22, 2019), https://www.supremecourt.gov/orders/courtorders/ 012219zor_8759.pdf [https://perma.cc/5CAN-QBLN]; see also Sarah Grant, Supreme Court Stays Injunctions in Trans Ban Case: What Happens Now?, LAWfARE (Jan. 22, 2019, 11:44 AM), https://www.lawfareblog.com/supreme-court-stays-injunctions-trans-ban-case-what-happensnow [https://perma.cc/C3HN-MRWE] (discussing this). In one case, a district court enjoined the new transgender restrictions, and the D.C. Circuit reversed and remanded that decision. See Doe 2 v. Trump, 315 F. Supp. 3d 474, 498 (D.D.C. 2018), rev'd, Doe 2 v. Shanahan, 755 F. App'x 19 (D.C. Cir. 2019).

6. Regents of Univ. of Cal. v. U.S. Dep't of Homeland Sec., 908 F.3d 476, 520 (9th Cir. 2018), cert. granted, 139 S. Ct. 2779 (2019). The Ninth Circuit also ruled that the DACA rescission was arbitrary and capricious under the Administrative Procedure Act (APA), Pub. L. No. 79-404, 60 Stat. 237 (1946) (codified as amended at 5 U.S.C. $\$ \S 551-559,701-706$ (2012)). 
While the substantive law in each of these cases is different, ${ }^{7}$ the approaches taken by courts reveal a methodological confusion that goes beyond substantive distinctions. The confusion arises because constitutional law has no uniform approach to rollbacks of inclusive policies. Such an approach is urgently needed, particularly in the areas of immigration, citizenship, and national security, where the Trump Administration has been most active.

President Trump's penchant for upending settled understandings in law, policy, and rhetoric complicates the courts' role. It is tempting to view President Trump as a rogue president who has compromised his own oath of office and thus merits more rigorous judicial review than other occupants of the White House. ${ }^{8}$ However, the Supreme Court has already cautioned against this course, noting that courts reviewing actions by President Trump are, as with judicial review of decisions by other presidents, necessarily reviewing "the Presidency itself." 9 Pivoting too hastily from courts' traditional deferential posture on national security and immigration can obscure the "delicate" touch required in assessing presidential statements and decisions. ${ }^{10}$ As the Court suggested in Trump v. Hawaii," the courts have to fashion rules that apply to all subsequent occupants of the White House-not just Donald Trump. ${ }^{12}$

Similarly, courts must recognize that in the context of democratic governance, administrative rescissions are a feature, not a bug. Individuals running for president regularly define their candidacies in

Id. This Article focuses only on the constitutional issues, although administrative law scholarship informs its analysis.

7. Transsubstantive legal norms have received increased attention from scholars. See RICHARD H. IFALLON, JR., IMPI.EMENTING THE CONSTITUTION 38 (2001) (analyzing implementation of constitutional norms); William Baude \& Stephen E. Sachs, The Law of Interpretation, 130 HARV. L. Riv. 1079, 1107-12 (2017) (discussing interpretive rules); Mitchell N. Berman, Constitutional Decision Rules, 90 VA. L. RLV. 1, 30-50 (2004) (analyzing prophylactic rules such as Miranda that promote compliance with constitutional rights); Robert M. Chesney, National Security liact Deference, 95 VA. L. RI: V. 136I, 1362-66 (2009) (discussing national security and forcign relations context); Kermit Roosevelt III, Constitutional (alcification: Ilow the Law Becomes What the Court Does, 91 VA. L. RI:v. 1649, 1650-52 (2005) (discussing links between judicial practice and legal norms); Lawrence Gene Sager, fair Measure: The Legal Status of Underenforced Constitutional Norms, 91 HARV. L. RI:V. 1212, 1213-37 (1978) (discussing how the selection of a legal standard causes under- or over-enforcement of norms).

8. See generally Andrew Kent el al., Faithful lixecution and Article II, 132 HArv. L. Rrv. (fortheoming 2019) (examining the origin of the U.S. Constitution's "faithful exccution" requirement upon the President).

9. Trump v. Ilawaii, $138 \mathrm{~S}$. Ct. 2392, 2418 (2018) (upholding on both constitutional and statutory grounds President Trump's proclamation limiting immigration from certain majorityMuslim countries, as well as North Korea and Venezucla).

10. Id.

11. $138 \mathrm{~S}$. Cl. 2392 (2018).

12. Id. at 2418 . 
contrast to the policies of the current chief executive. ${ }^{13}$ In the administrative law sphere, "exits" from a previous administration's initiatives are a stock in trade of presidential transitions. ${ }^{14}$ Moreover, these pivots can stem from fundamental disagreements about the contours of constitutional law. One administration's expansion of rights through agency action can be a subsequent administration's bureaucratic overreaching.

Agency expansions of rights can trigger three kinds of conflicts. First, and perhaps most obviously, an expansive agency view of rights may conflict with a subsequent administration's view of its constitutional responsibility to protect the nation's safety. For example, former Secretary of Defense James Mattis asserted that the need to maintain combat readiness and foster the cohesion of military units required a partial rollback of the inclusive policy on transgender service members announced by the Obama Administration. ${ }^{15}$ Second, as in the reaction to President Obama's immigration initiatives such as DACA, ${ }^{16}$ expansions of rights or benefits through unilateral agency action may trigger concern

13. James Risen, The Executive Power Awaiting the Next President, N.Y. TIMES (June 22, 2008), https://www.nytimes.com/2008/06/22/weekinreview/22risen.html [https://perma.cc/ E9NN-KRT2] (reporting that then-candidate Barack Obama was "sharply critical" of the "expansive" view of presidential power taken by then-president George W. Bush). Candidate Donald Trump's criticism of President Obama was more personal and invidious, in its false premise that Obama was not a natural-born citizen of the United States. See Maggie Haberman \& Alan Rappeport, Trump Drops False 'Birther' Theory, but Floats a New One: Clinton Started It, N.Y. TIMES (Sept. 17, 2016) https://www.nytimes.com/2016/09/17/us/politics/donald-trumpbirther-obama.html [https://perma.cc/46RL-4LLM] (reporting that, after five years of steadfastly maintaining his "birther" claim, then-candidate Trump backed away from that position in the final weeks of the 2016 campaign).

14. J.B. Ruhl \& James Salzman, Presidential Exit, 67 DukE L.J. 1729, 1732-34 (2018) [hereinafter Rulh \& Salzman, Presidential Exit]; J.B. Ruhl \& James Salzman, Regulatory Exit, 68 VAND. L. REV. 1295, 1297 (2015) [hereinafter Ruhl \& Salzman, Regulatory Exit].

15. Doe 2 v. Shanahan, 917 F.3d 694, 699 (D.C. Cir. 2019).

16. See Texas v. United States, 809 F.3d 134, 180 (5th Cir. 2015), aff'd by an equally divided Court, 136 S. Ct. 2271 (2016). 
about excessive use of government power. ${ }^{17}$ Third, rights may conflict, spurring efforts to halt or temper reforms. ${ }^{18}$

Each of these rationales for rescission also complicates the analysis of both the rollback and the previous measure as forms of what scholars have recently called administrative constitutionalism. Groundbreaking works of administrative constitutionalism have related how administrative agencies have expanded the content of constitutional rights through rules on conscientious objection from the military draft, ${ }^{19}$ welfare programs, ${ }^{20}$ and employment law. ${ }^{21}$ The measures that the Trump

17. See Karen M. Tani, Administrative Equal Protection: Federalism, the Fourteenth Amendment, and the Rights of the Poor, 100 CORNELL L. REv. 825, 872-73 (2015) [hereinafter Tani, Administrative Equal Protection] (noting that after New Deal federal welfare officials and their successors had sought for over twenty years to combat arbitrary and invidious state policies, a longtime official wrote an influential memorandum warning against tying federal funding to southern states' integration); $c f$. KAREN M. TANI, STATES OF DEPENDENCY: WELFARE, RIGHTS, AND AMERICAN GOVERNANCE, 1935-1972, at 248 (2016) [hereinafter TANI, STATES OF DEPENDENCY] (describing 1960s federal officials' politically-based wariness about taking a public stance favoring vigorous enforcement of a newly enacted federal civil rights statute barring racial discrimination in programs receiving federal funds). Earlier, U.S. military lawyers had argued after America's entrance into World War I that the Wilson Administration's expansive definition of conscientious objector status - crafted by then-War Department lawyer and future Supreme Court Justice Felix Frankfurter-exceeded executive power under a statute that had narrowly defined conscientious objection to the draft. See Jeremy K. Kessler, The Administrative Origins of Modern Civil Liberties Law, 114 CoLUM. L. REv. 1083, 1111-22, 1138-39 (2014) (discussing Justice Frankfurter's memorandum on the subject and military lawyers' opposing argument that Justice Frankfurter's expansive definition, rooted in civil liberties, conception of the military as embodying American freedoms, and presidential discretion contravened clear statutory command).

18. See generally New York v. U.S. Dep't of Commerce, 351 F. Supp. 3d 502 (discussing, but then rejecting, the position taken by the Justice Department that a citizenship question on the census was necessary to implement Voting Rights Act and implement one-person-one-vote principle by preventing vote dilution). This abiding concern animated the D.C. Circuit's invalidation of Federal Communications rules requiring broadcasters to adopt certain kinds of affirmative action programs. See Lutheran Church-Mo. Synod v. FCC, 141 F.3d 344, 353-56 (I).C. Cir. 1998).

19. Kessler, supra note 17.

20. See TANI, STATIS OF DIPINNIINCY, supra note 17; Tani, Administrative Equal Protection, supra note 17.

21. See, e.g. Sophia Z. Lee, Race, Sex, and Rulemaking: Administrative Constitutionalism and the Workplace, 1960 to the Present, 96 VA. L. RI:V. 799, 800-01 (2010). Other scholars have addressed how agencies can set up internal watchdogs that promote constitutional values and moderate agency moves that may overreach, especially in national security. See generally Shirin Sinnar, Protecting Rights from Within? Inspectors General and National Security Oversight, 65 SIAN. L. RI:V. 1027 (2013) (discussing safeguards against government overreaching provided by inspectors general); Margo Schlanger. Intelligence Legalism and the National Security Agency's Civil liberties Gap. 6 HARV. NAl'l. SI:CURITY J. 112, 194 (2015) (arguing that placement of privacy officers in compliance units has beneficial effects, but it also frustrates integration of civil libertics conecrns into initial policy formulation). 
Administration has sought to rescind fall under administrative constitutionalism's rubric. In each case, prior administrations have sought to expand conceptions of rights beyond what prior case law or the express language of the Constitution or statutes provided. ${ }^{22}$

In seeking to roll back these measures, the Trump Administration has invoked its constitutional responsibility, the limits on presidential power, and prior measures' failure to adequately protect other rights. Rescission is therefore not merely about a new democratically elected president rolling back the product of a predecessor's constitutional vision; it also requires courts to sort out competing visions of administrative constitutionalism. Because the work of administrative constitutionalists has centered on a rich historical account of executive branch officials' perspectives and decisions, it has tended to focus less on the normative analysis of judicial approaches or the normative ordering of competing versions of constitutionalism. ${ }^{23}$ This Article aims to fill that gap.

This Article's approach addresses threshold agency measures. In this Article, threshold measures concern fundamental access points. To qualify as a threshold, access must include an agency or entity's application of criteria that limit participation based on race, gender, or sexual orientation, restrict the ability to work legally and remain in the United States, or adversely affect participation in the political system. Moreover, to qualify as threshold rescissions, agency shifts must adversely affect reliance interests.

This approach covers a narrow subset of agency rescissions. Most regulatory changes, including those addressing regulation of industrial, commercial, or financial processes, would not qualify. In other words,

22. See Peter Margulies, Taking Care of Immigration Law: Presidential Stewardship, Prosecutorial Discretion, and the Separation of Powers, 94 B.U. L. REV. 105, 107 (2014) (asserting that DACA stemmed from a vision of inclusion and equity in pre-presidential writings of then-senator Barack Obama and echoed earlier uses of presidential authority to safeguard "intending Americans" from adverse actions by non-federal sovereigns). Scholars have also cautioned that expanding certain rights beyond judicial precedent or express statutory parameters may impinge on others' rights or trigger other adverse effects. See David E. Bernstein, Antidiscrimination Laws and the Administrative State: A Skeptic's Look at Administrative Constitutionalism, 94 NOTRE DAME L. REV. 1381, 1387-89 (2019) (criticizing Obama Administration officials' advice to college administrators to strengthen procedures for investigating and adjudicating students' sexual assault claims as impinging on rights of the accused and suggesting that perceived excesses of this policy guidance reveal normative gaps in administrative constitutionalist literature).

23. To be sure, scholars have addressed the interaction of case law and administrative constitutional visions. See Tani, Administrative Equal Protection, supra note 17, at 885-99. However, for administrative constitutionalists, historical and descriptive questions have been more pressing than normative concerns, in part because this emerging strand of scholarship has viewed much traditional court-centered legal academic work as neglecting the study of administrative officials' thought. 
this Article does not aim to constitutionalize vast stretches of administrative law. Most proposed changes will continue to be assessed largely under the Administrative Procedure Act (APA). ${ }^{24}$ Most discretionary agency decisions, including individual decisions on whether to prosecute or commence regulatory proceedings, will not be covered and indeed may not be reviewable at all. ${ }^{25}$

This Article argues that courts should subject threshold rescissions to intermediate scrutiny. Under intermediate scrutiny, a party challenging a threshold rescission would need to show only that the rescission was not tailored to serve a significant government interest. ${ }^{26}$ Particularly in the national security and foreign relations arena, this standard is more robust than the deferential review that courts usually conduct. ${ }^{27}$ Moreover, this standard does not require proof of discriminatory intent, which current equal protection doctrine would require in most other contexts. ${ }^{28}$

Three factors justify this more robust standard. First, threshold rescissions impair reliance interests. For example, the transgender service members who disclosed their identity after the Obama Administration announced its more inclusive policy would be at risk under a total rescission. ${ }^{29}$ Indeed, the 2018 Mattis policy that restores some limits recognizes this problem by giving certain transgender service members the right to continue in the military. ${ }^{30}$ Second, courts' institutional

24. Pub. L. No. 79-404, 60 Stat. 237 (1946) (codified as amended at 5 U.S.C. $\$ \$ 551-559$, 701-706 (2012)).

25. See Heckler v. Chaney, 470 U.S. 821, 831-32 (1985) (holding that most agency decisions not to initiate proceedings against specific targets were unreviewable because they involved balancing variables including available agency resources regarding which agency had superior knowledge, and courts were ill-equipped to intervene). Agency rescissions may trigger statutory issucs-including those under the APA - but those issues are not this Article's focus. See FCC v. Fox Television Stations, Inc., 556 U.S. 502, 530 (2009) (upholding FCC change to application of broadcast indecency policies under $\Lambda \mathrm{P} \Lambda$ ). In Fox, Justice Scalia disparaged the notion that a mere regulatory change, even one involving constitutional issues such as free speech, should necessarily trigger more exacting scrutiny under the APA. Id. at 515-16. However, Justice Scalia did note that in explaining a rescission, an agency should take into account "serious reliance interests." Id. at 515 . This Article stems from a comparable intuition, although it defines reliance interests in a broader fashion. For analysis of fox, sce William W. Buzbee, The Tethered President: Consistency and Contingency in Administrative Law, 98 B.U. L. REv. 1357, 13991400 (2018); Gillian I: Metzger, Ordinary Administrative Law as Constitutional Common Law. 110 COL.UM. I. Rı:v. 479, 483-86 (2010).

26. See Packingham v. North Carolina, 137 S. Ct. 1730, 1736 (2017).

27. See Trump v. Ilawaii, 138 S. Ct. $2392,2419-20$ (2018).

28. See Washington v. Davis, 426 U.S. 229, 239 (1976).

29. See German Lope\%, Trump's Ban on Transgender Troops, lixplained, Vox (Jan. 22. 2019. 11:12 $A \mathrm{M})$. https://www.vox.com/identities/2017/7/26/16034366/trump-transgendermilitary-ban |https://perma.ce/4K9l- $\Lambda 7 \mathrm{~TB} \mid$.

30. See Memorandum from James N. Mattis, Sec'y of Def., U.S. Dep't of Def., to Donald J. Trump, President of the U.S. (Feb. 22, 2019), https://media.defense.gov/2018/Mar/23/ 
competence favors a more robust standard; courts have the benefit of prior administrative fact-finding favoring a more inclusive measure. ${ }^{31} \mathrm{On}$ the census, for example, a succession of officials from both parties supported the Census Bureau's expert judgment that a citizenship question would deter responses. ${ }^{32}$ Third, a previously promulgated inclusive measure will often have a significant quantum of support in Congress. DACA, for example, enjoyed a substantial quantum of bipartisan legislative support. ${ }^{3}$

Robust means-ends scrutiny would require the government to show more in threshold rescissions. On the rescission of the Obama Administration's inclusive transgender military policy, intermediate scrutiny would disaggregate the rescission's components. Courts should

2001894037/-1/-1/0/MILITARY-SERVICE-BY-TRANSGENDER-INDIVIDUALS.PDF [https://perma.cc/5XUQ-Z6S9].

31. The Supreme Court has repeatedly stressed courts' relative lack of expertise and access to data on difficult national security decisions. See Trump, 138 S. Ct. at 2419 ("[W] hen it comes to collecting evidence and drawing factual inferences [regarding national security] . . 'the lack of competence on the part of the courts is marked" (quoting Holder v. Humanitarian Law Project, 561 U.S. 1, 34 (2010))); $c f$. Chesney; supra note 7, at 1362-66 (discussing traditional judicial deference).

32. La Unión del Pueblo Entero v. Ross, 353 F. Supp. 3d 381, 392-95 (D. Md. 2018); New York v. U.S. Dep't of Commerce, 315 F. Supp. 3d 766, 775 (S.D.N.Y. 2018).

33. See Kevin R. Johnson, Lessons About the Future of Immigration Law from the Rise and Fall of DACA, 52 U.C. DAvIS L. REV. 343, 368 (2018) (noting support for DACA from Speaker Paul Ryan and Senator Orrin Hatch). The congressional support for DACA, coupled with a history of presidential actions to protect intending Americans, was arguably sufficient to constitute legislative acquiescence. See Margulies, supra note 22, at 107-08. Legislative acquiescence would entitle the inclusive measure to a middling level of judicial deference under Justice Jackson's landmark framework parsing executive power. See Youngstown Sheet \& Tube Co. v. Sawyer, 343 U.S. 579, 635-38 (1952) (Jackson, J., concurring); see also id. at 610-11 (Frankfurter, J., concurring) (discussing importance of historical "gloss" gleaned from pattern of congressional-executive branch interactions over time); NLRB v. Noel Canning, $134 \mathrm{~S}$. Ct. 2550, 2567 (2014) (affirming the importance of historical perspective on active and tacit understandings between the political branches); cf. Patricia L. Bellia, The Story of the Steel Seizure Case, in 233, 273-75 Presidential POWER STORIES (Christopher H. Schroeder \& Curtis A. Bradley eds., 2009) (discussing the history of Youngstown litigation). See generally Curtis A. Bradley \& Trevor W. Morrison, Historical Gloss and the Separation of Powers, 126 HARV. L. REV. 411 (2012) (tracing the development of the view that a pattern of legislative acquiescence broadens judicial deference to executive power); Brett M. Kavanaugh, Congress and the President in Wartime, LAwfare (2017) (reviewing David Barron's book, Waging War: The Clash Between Presidents and Congress, 1776 to $I S I S$ ) (discussing challenges in determining where among Justice Jackson's categories the particular exercise of wartime executive power fits), www.lawfareblog.com/congress-and-president-wartime [https://perma.cc/29ML-LQAN]. A measure like DACA may be too recent to claim the mantle of historical "gloss." Moreover, approval of DACA was certainly not unanimous among legislators. However, demonstrations of bipartisan support, such as Speaker Ryan and Senator Hatch's support for DACA, go some way toward showing the rescinded measure's democratic pedigree. 
acknowledge the 2018 Mattis policy's grandfathering in of certain transgender service members and its inclusion of some individuals who identify with a gender other than their assigned one. Moreover, a significant component of the 2018 policy-its requirement of thirty-six months of stability for new recruits-would pass muster. However, the 2018 policy's bar on accession of transitioned individuals would fall, as would its bar on retention of persons outside of the grandfathered group who in the future require accommodations or medical treatment. The census citizenship question would require more testing, while the rescissions of DACA and TPS respectively would require more comprehensive explanation than the Trump Administration has provided. ${ }^{34}$

A more deliberative democracy would emerge from disaggregating the parts of the 2018 transgender policy and requiring more elaboration about the census, DACA, and TPS. Courts do a disservice to both democracy and deliberation by failing to separately parse the transgender policy's principal features and analyzing each on its own merits. ${ }^{35}$ That more nuanced analysis also highlights the 2018 policy's stilted and static account of unquestioned virtues such as unit cohesion. With respect to the census, DACA, and TPS, the additional elaboration required by the approach taken here would realign incentives, encouraging an administration to develop sound justifications before it issued a rescission in the first place. That prophylactic ex ante effect will surely aid the cause of deliberation that the Framers embraced.

By allowing both continuity and flexibility in addressing a predecessor's inclusive initiatives, the approach taken here also seeks to provide a normative dimension to the administrative constitutionalist literature, which has often stressed descriptive and historical perspectives. Highlighting the judicial role could be viewed as a distraction from administrative constitutionalists' focus on agencies as an antidote to preoccupation with the courts, Congress, or the President. However, perhaps this piece can instead facilitate further engagement between normative analysis and administrative constitutionalism's salutary historical work.

This Article unfolds in four parts. Part I discusses the approach taken here, introducing administrative constitutionalism as a framework, discussing its normative tensions, and addressing the need for more robust means-ends scrutiny of threshold rescissions. Part II analyzes the

34. In the census, $D \wedge C \wedge$, and TPS rescissions, challengers would also be able to show discriminatory intent, which the traditional test requires, although the approach outlined in this Article does not.

35. See Doe 2 v. Shanahan, 755 I. App'x 19, 22-23 (1).C. Cir. 2019) (contrasting Secretary of Defense Mattis's policy and President 'Trump's tweets in the course of vacating a district court injunction against the new transgender restrictions). 
2018 transgender policy in light of this approach. Part III discusses the census. Part IV addresses both DACA and TPS. Each situation entails competing versions of administrative constitutionalism. Ranking those iterations through means-ends scrutiny will help safeguard deliberative democracy.

\section{Administrative Constitutionalism AND THRESHOLD RESCISSIONS}

Scholars of administrative constitutionalism have argued that agencies regularly make decisions that revise or expand constitutional interpretation. ${ }^{36}$ Yet, as these scholars have recognized, since agencies are a "they," not an "it,"37 decisions that expand certain aspects of constitutionalism can also trigger pushback from regulatory colleagues. ${ }^{38}$ Indeed, that pushback often entails competing visions of constitutionalism, stemming from disagreements regarding agency responsibility, authority, and concern for conflicting rights. ${ }^{39}$

36. See Lee, supra note 21 , at 800-01; TANI, STATES OF DEPENDENCY, supra note $17_{2}$ at 246; Gillian E. Metzger, Administrative Constitutionalism, 91 TEX. L. REv. 1897, 1901-02 (2013) (discussing issues of legitimacy in agency actions that rely on constitutional interpretation, particularly when that interpretation is only thinly acknowledged in agency rationale). Administrative constitutionalist scholars have noted parallels between this school of thought and other recent work on how non-judicial actors construct constitutional meaning. See Keith E. Whittington, Constructing a New American Constitution, 27 CONST. Comment. 119, 120, 128 (2010); see also Bertrall L. Ross II, Embracing Administrative Constitutionalism, 95 B.U. L. REV. 519, 553-61 (2015) (analyzing how administrative interpretations aid in the process of "experimentalism" and thus further the adaptation of constitutional principles to contemporary needs).

37. In other words, agencies are not unitary; they often feature tensions between different officials and units within the agency that interact with different stakeholders and have competing agendas. Scholars from a range of points on the ideological spectrum recognize this reality. See Rebecca Ingber, Bureaucratic Resistance and the National Security State, 104 IOWA L. REV. 139, 164-65 (2018); Neomi Rao, Public Choice and International Law Compliance: The Executive Branch is a "They," Not an "It," 96 MINN. L. REV. 194, 197 (2011); Tani, Administrative Equal Protection, supra note 17, at 864-67 (discussing tensions within federal agencies regulating state provision of welfare benefits regarding scope of federal authority to require that states allocate benefits fairly and equally).

38. See Memorandum from Rufus Miles, Admin. Assistant Sec'y, Dep't of Health, Educ. and Welfare, to the Sec'y, Dep't of Health, Educ. and Welfare (Jan. 9, 1960) (on file with the author) (cautioning administrators against using broad constitutional reading to support what Miles viewed as an unduly aggressive use of threat of federal funding termination to shape state welfare criteria); cf. Tani, Administrative Equal Protection, supra note 17, at 872-73 (discussing Miles's view). I am indebted to Professor Tani for making a copy of this memorandum available.

39. See Miles, supra note 38 , at 3 (urging administrators to stay within agency's "responsible exercise of its proper role without over-reaching"). 


\section{A. Administrative Constitutionalism and Individual Rights}

Administrative constitutionalists have focused most closely on agency expansions of rights. They have argued, based on careful and compelling review of agency records and correspondence, that agencies have promoted rights beyond what courts at a particular time required in a range of areas, including conscientious objection to the military draft, welfare benefits, and fair employment. ${ }^{40}$ For example, Karen Tani writes, officials at agency precursors of today's Department of Health and Human Services invoked constitutional values of due process and equal protection to curb states that sought to restrict on moralistic or other grounds indigent families' access to government benefits. ${ }^{41}$ Sophia Lee has studied efforts by the Federal Communications Commission to promote fair employment and diverse workplaces for broadcast licensees. $^{42}$ Jeremy Kessler has written about the efforts of War Department lawyers like future Supreme Court Justices Felix Frankfurter and Harlan Stone. ${ }^{43}$ During World War I, Frankfurter and Stone expanded the definition of conscientious objector status beyond Congress's definition to include "unorganized" objectors who did not belong to any distinct religious group but nonetheless expressed sincere and profound opposition to participation in armed conflict. ${ }^{44}$ In a number of the cases studied by administrative constitutionalist scholars, the courts or Congress eventually expanded rights that the agencies had previously recognized, although in most cases neither branch went as far in expanding rights as the high-water mark in agency officials' own aspirations.

40. See TANi, States OF DEPEnDENCY, supra note 17, at 71 (welfare benefits); Kessler, supra note 17, at 1133-36 (conscientious objection); Lee, supra note 21, at 801 (employment); Reuel I. Schiller, Comment, The Administrative State, Front and Center: Studying Law and Administration in Postwar America, $26 \mathrm{~L} \wedge \mathrm{W} \&$ HIST. REV. 415, 422 (2008) (free speech and censorship).

41. See generally Tani, Administrative Equal Protection, supra note 17, at 867-73 (discussing agency's interactions with Louisiana over state rules that limited the benefits available to mothers with children born out of wedlock).

42. See I,ec, supra note 21 , at $811-18$ (discussing FCC officials' emerging interest in Kennedy administration in requiring licensees to practice fair employment).

43. Kessler, supra note 17.

44. Kessler, supra note 17, at 1111-23.

45. See Tani, Administrative liqual Protection, supra note 17, at 884-90 (discussing the Warren Court's case law and other pro-recipient decisions, although as part of the ebb and flow of constitutional law noting later more pro-state precedents of the Burger Court, such as Dandridge v. Williams, 397 U.S. 471 (1970), which limited constitutional claims by upholding state discretion to cap total welfare benefits available to any family per month so that parents with more dependent children received proportionately reduced amounts for each child). During the New Deal and World War II, federal agency lawyers had an extraordinary influence on the legislative process, including close contact with members of Congress drafting statutes and 
Yet the administrative constitutionalism revealed in such innovations was arguably just one of several competing forms of administrative constitutionalism within the agency and among its many stakeholders. To temper the vision of expanded rights that administrative constitutionalism furthered, another competing vision stressed the limited powers of the federal government. For example, when federal welfare officials sought to invoke the Constitution to prevent Louisiana from conditioning receipt of welfare benefits on a parent's provision of a "suitable home" for children, a longtime federal welfare administrator warned that neither the Constitution nor any federal statute allowed officials to use federal funds as leverage to prod the state into compliance with officials' views. ${ }^{46}$ As the senior official cautioned, an expansive administrative constitutional interpretation would constitute the exercise of "unrestrained power," "usurp the proper role of the courts," and "over-reach the role of the Executive Branch." ${ }^{47}$

Similarly, government lawyers opposed to the expansive vision of conscientious objector status articulated by Justices Frankfurter and Stone argued that Congress, in exercising its constitutional power to set rules for the armed forces, had expressly demarcated the bounds of that status. ${ }^{48}$ For these internal critics, expanding the definition beyond Congress's express limits would contravene Congress's authority. ${ }^{49}$ While the courts ultimately held that the First Amendment required a broader definition, that development occurred much later-well after the conclusion of World War I. ${ }^{50}$ But Justices Frankfurter and Stone's push past Congress's limits occurred immediately. And Justice Frankfurter's memorandum on the subject devoted no space whatsoever to the separation of powers concerns raised by his proposed policy or even to

legislative history, as well as including legislative history in briefs in those pre-Internet days when such materials were often difficult for other litigants to find. See Nicholas R. Parrillo, Leviathan and Interpretive Revolution: The Administrative State, the Judiciary, and the Rise of Legislative History, 1890-1950, 123 YALE L.J. 266, 338-42 (2013). Agency influence during this formative period surely contributed to administrators' sense of the leverage they could wield in both interpretation and implementation.

46. See Miles, supra note 38.

47. $I d$. at 2-3. Courts eventually found that some of these state practices violated federal law. See Tani, Administrative Equal Protection, supra note 17, at 867-73 (discussing the Louisiana "suitable home[s]" controversy).

48. See Kessler, supra note 17, at 1126-27.

49. Id.

50. Cf. id. at 1161-63 (discussing the evolution of Justices Frankfurter and Stone's thinking after their appointments to the Supreme Court and the latter's increased focus on judicial protections for civil liberties). 
specific discussion of the First Amendment, preferring to center on executive discretion. ${ }^{51}$

In other cases, competing visions of administrative constitutionalism stressed the rights or interests of other individuals. For example, the senior federal official's warning about overreaching in policing restrictive state welfare rules also cautioned about the negative impact of terminating federal funds to the state on other indigent individuals or institutions that received benefits. ${ }^{52}$ A few years after the senior official's warning, Congress enacted legislation that conditioned receipt of federal funding on compliance with federal antidiscrimination laws. ${ }^{53}$ Courts have upheld such legislation as an appropriate exercise of legislative power under the Spending Clause. ${ }^{54}$ However, in the absence of such clear legislative authority, the senior official's concern was legitimate. ${ }^{55}$ One can argue that swift and decisive action was necessary to deter punitive and moralistic state policies, especially when those policies also contained a racial dimension. But counterarguments should not obscure the importance of a full internal policy debate as well as legislative input. Some officials' push to scuttle state restrictions may have submerged these other considerations.

In addition, critics of certain iterations of administrative constitutionalism contended that the expansive readings of rights undermined federal responsibility for national security grounded in the Constitution itself. Government lawyers opposing Justices Frankfurter and Stone's expansive reading of conscientious objector status argued strenuously that the military needed all potential personnel for the war

51. Id. at 1111-23; Justice Pelix Frankfurter, Memorandum for the Secretary of War: Treatment of Conscientious Objectors 2 (Sept. 18, 1917) (discussing conscientious objector status as an "administrative or military problem concerning the use to which certain men called to the colors are to be put in view of their peculiar fitness or unfitness") (manuscript on file with the author). 1 am indebted to Jeremy Kessler for access to a copy of this memo.

52. See Miles, supra note 38 , at 2 (warning of consequences of hypothetical federal funding cut-off to state "land-grant colleges" or "church-supported schools"). Federal funding terminations continue to be a fraught endeavor. See Eloise Pasachoff, Agency Enforcement of Spending Clause Statutes: A Defense of the Funding Cut-Off, 124 YALI: L.J. 248, 334 (2014) (urging more tenacious federal enforcement of grant conditions).

53. See Title VI of the Civil Rights $\Lambda \mathrm{ct}$ of 1964 , Pub. L. No, 88-352, $\$ \$ 601-605,78$ Stat. $241,252-53$ (codified as amended at 42 U.S.C. $\$ \$ 2000 d-2000 d-7(2012)$ ).

54. See Nat'l led'n of Indep. Bus. v. Scbelius, 567 U.S. 519, 576-78 (2012) (analyring parameters of Congress's spending power).

55. Current concerns expressed by some Justices of the Supreme Court take this argument a step further. asserting that the Constitution forbids excessive delegations from Congress to agencies. See (Gillian E: Met/ger, 1930s Redux: The Administrative State Under Siege, 131 II Arv. I. RI:V. 1, 24-28 (2017). But questions about whether agency action in a particular case fits within Congress's delegation do not rely on this more radical position. 
effort, which would be hobbled by less than full participation. ${ }^{56}$ The relatively modest number of conscientious objectors, even under Justices Frankfurter and Stone's more expansive paradigm, suggests that this fear was overblown. Nevertheless, it is important to acknowledge this strand of opposition, which stems from the legitimate government interest in successful prosecution of the war effort. ${ }^{\text {st }}$

In sum, celebrating administrative constitutionalism is both salutary and perilous. Acknowledging the resourceful responses of sometimes beleaguered administrators to unfairness and inequality is important and overdue. A deep descriptive dive into those courageous administrators' actions reveals much about the origins of constitutional rights. It also offers, as in the welfare officials' vision, tantalizing hints of a more positive government duty to assist people living in poverty. Yet, these salutary effects could also benefit from a normative frame that considers transitions to and from such expansive readings in light of competing concerns, which often themselves have constitutional ramifications.

\section{B. The Role of the Courts in Assessing Threshold Rescissions}

Many rescissions of administrative constitutionalist measures should not trigger constitutional concerns. In some cases, resulting friction plays out in both the political realm and the court of public opinion. In other cases, the APA alone is sufficient to address the issue. ${ }^{58}$ Under this Article's approach, the Constitution is relevant to what this Article calls "threshold" rescissions.

An agency's threshold rules can be internal or external. Either way, they govern access to basic goods and attributes, such as baseline criteria for participation in the entity, or core interests with a constitutional dimension, such as the ability to remain in the United States or the apportionment of political representatives. ${ }^{59}$ Rescissions of such threshold rules trigger substantial collateral impacts, through either creation of orphan groups protected by earlier rules but subject to post-

56. Kessler, supra note 17 , at 1090.

57. See generally Matthew C. Waxman, The Power to Wage War Successfully, 117 CoLUM. L. REV. 613 (2017) (discussing this interest as articulated in 1917 by Charles Evans Hughes).

58. See Ruhl \& Salzman, Presidential Exit, supra note 14, at 1731-32, 1746 n.83; cf. FCC v. Fox Television Stations, Inc., 556 U.S. 502, 530 (2009) (upholding turn to broader FCC application of broadcast indecency policies); Metzger, supra note 25, at 483-84 (critiquing Fox). While this Article's approach would have required more exacting review in Fox, a full analysis of that case is beyond this Article's scope.

59. An agency's rules governing the ability of an entity to broadcast speech would also fit under this rubric. But see Fox, 556 U.S. at 515-16 (asserting that an agency's pivot to more vigorous regulation of allegedly indecent speech on public broadcasts, while it touched on matters governed by the First Amendment, did not necessarily require additional justification under the APA, if the agency action was itself constitutional). 
rescission discrimination, or disruption of collaborative endeavors involving both the direct subject of regulation and third parties. This creates a narrow subset of changes subject to constraint. Most regulatory changes, including those addressing regulation of industrial, commercial, or financial processes, do not constitute threshold rescissions.

As an example of a threshold rescission, consider President Woodrow Wilson's efforts to segregate federal officials. Until the Wilson Administration, the federal civil service had been racially integrated since the nineteenth century. ${ }^{60}$ This institutional commitment to racial integration reflected a distinctively administrative commitment to equality, since courts had signaled by 1896 that government segregation was constitutional. ${ }^{61}$ Wilson forcefully resegregated the federal government, fundamentally changing working conditions on the basis of race. ${ }^{62}$ Pivoting back toward equality, after World War II President Harry Truman changed the military's threshold institutional criteria when he required racial integration of U.S. armed forces. ${ }^{63}$ Congress did not mandate this, ${ }^{64}$ and the Supreme Court did not prohibit segregation in public schools until several years later. ${ }^{65}$ One can understand former Defense Secretary Ashton Carter's lifting of the ban on transgender individuals in the same light. ${ }^{66}$ Former Defense Secretary Mattis's restrictions on transgender service in and accession to the armed forces count as a partial threshold rescission of Carter's policy. ${ }^{67}$

There are three reasons that threshold rescissions warrant higher scrutiny than other measures, even absent proof that such rescissions involved the intent to discriminate against a suspect or quasi-suspect class defined by race, ethnicity, gender, sexual orientation, religion, or national

60. See David I. Bernstein, Philip Sober Controlling Philip Drunk: Buchanan v. Warley in IHislorical Perspective, 51 V^ND. L. REv. 797, 800 (1998).

61. See Plessy v. Ferguson, 163 U.S. 537, 550-51 (1896), overruled by Brown v: Bd. of Iiduc., 347 U.S. 483 (1954).

62. See Bernstein, supra note 60.

63. See Robert Knowles, The Inlertwined Fates of Affirmative Action and the Military, 45 I.oY. U.CIII. L.J. 1027, 1049 (2014).

64. Theo Lippman, Jr., For Truman, Desegregation Was a Political Move, Balt. Sun (^ug. 9. 1998). https://www.baltimoresun.com/news/bs-xpm-1998-08-09-1998221064-story.html |https://perma.ce/L.MI,3-P2X3| ("|I|n licbruary 1948, Truman called on Congress for "modern, comprehensive civil rights laws.' Congress more or less ignored that, so black leaders called for exccutive action.").

65. See Brown, 347 U.S. at 495.

66. See Press Release. Dep't of Def.. Secretary of Defense Ash Carter Announces Policy on Transgender Service Members (June 30, 2016), https://dod.defense.gov/News/NewsReleases/News-Release- $V$ iew/Article/82 1675/secretary-of-defense-ash-carter-announces-policy -for-transgender-service-members/ /hitps://perma.cc/6XI3J-MPYT\}.

67. See Memorandum from Donald J. Trump, supra note 2. 
origin. ${ }^{68}$ First, threshold rescissions adversely affect reliance interests. Second, they typically do not pose the same threat to institutional competence posed by review of other rescissions. Third, threshold rules that a new administration seeks to rescind often have substantial support in the legislative sphere, demonstrating a significant degree of congressional acquiescence. This Article considers each in turn.

Many threshold rescissions leave orphan groups in their wake, which had received access or other goods under a previous expansion of threshold criteria. A rescission will prejudice the interests of such groups. Consider again President Wilson's resegregation of the federal government.

While African-American officeholders were not formally terminated, a cluster of related measures made them unwelcome. ${ }^{70}$ In some cases, senior officials pursuing Wilson's policy shifted African-American civil servants into separate units that were later eliminated. ${ }^{71}$ Transfers were particularly common when African-American men had previously supervised white female civil servants. ${ }^{72}$ A number of the most prominent African-American officials retired shortly after the segregationist policies' implementation. ${ }^{73}$ Within the Wilson Administration, officials justified these adverse impacts not by overt appeals to animus, but instead by references to the supposed "friction" between the races that segregation would ease. ${ }^{74}$ Nevertheless, the signal received by white middle managers in the administration was clear: "Forces defending racial equality ... gave way to long-latent desires for discrimination.",75

68. Under current doctrine, heightened scrutiny would require either an express classification based on suspect or quasi-suspect criteria, proof of intentional discrimination when express discrimination was absent, or interference with fundamental rights such as voting. See Washington v. Davis, 426 U.S. 229, 239 (1976) (requiring proof of discriminatory purpose). See generally Richard H. Fallon, Jr., Tiers for the Establishment Clause, 166 U. PA. L. REV. 59 (2017) (discussing doctrine dividing scrutiny into tiers depending on the nature of the classification at issue).

69. Nancy J. Weiss, The Negro and the New Freedom: Fighting Wilsonian Segregation, 84 Pol. SCI. Q. 61, 61 (1969).

70. See generally, e.g., id. (discussing racially charged measures undertaken by the Wilson administration).

71. See id. at 64.

72. Id.

73. See id. at 66 .

74. Id. at 71 ("Wilson, dismissing any political considerations, "said that the policy of segregation had been enforced for the comfort and best interests of both races in order to overcome friction." ). See generally Christine A. Lunardini, Standing Firm: William Monroe Trotter's Meetings with Woodrow Wilson, 1913-1914, 64 J. NEGRO HIST. 244 (1979) (listing the conversations President Wilson had with William Monroe Trotter on the Wilson Administration's “justifications").

75. Weiss, supra note 69 , at 65. 
Grandfathering in the subjects of a Wilsonian threshold rescission is a necessary but insufficient safeguard for reliance interests. In the Wilson example, African-American civil servants were nominally allowed to keep their jobs. ${ }^{76}$ Nevertheless, they were subjected to an array of measures, formal and informal, that made their position virtually impossible to maintain. ${ }^{77}$ In today's transgender exclusion context, the Mattis memorandum's grandfathering of certain current service members will not prevent other exclusionary measures, ranging from transfers to an atmosphere of indignities that recalls the treatment of AfricanAmerican civil servants in the Wilson Administration. ${ }^{78}$ In both cases, the rescission itself is a strong signal that senior officials have no interest in enforcing the rights of the orphaned group. That signal will empower others within the institution to act on their most invidious instincts and discourage members of the institution who seek to live up to both the letter and spirit of the military's "commitment."

In other contexts, even if reliance interests are less acute, a threshold rescission will impose severe direct and collateral impacts. In the census context, shifts in questions can depress the count, shifting apportionment of political representatives and skewing other metrics based on the count, including those shaping government funding, business planning, philanthropic giving, and scholarship. ${ }^{79}$ The rescission of benefits such as DACA and TPS can affect individuals who have embarked on life plans such as higher education or skilled employment; it can also affect individuals or entities who have collaborated with the recipient on such projects. $^{80}$

Two other factors support a heightened standard of review for rescissions: institutional competence and legislative acquiescence. First consider institutional competence. ${ }^{81}$ In a venerable justification for judicial deference, particularly in areas such as national security and foreign affairs, courts assert that they lack access to information about the questions at issue, while the political branches have many more resources

76. See id. at 64 .

77. See id.

78. See Alan Okros \& Denise Scott, Gender Identity in the Canadian Forces: A Review of Possible Impacts on Operational liffectiveness, 41 ARMI:D l'ORCES \& SOC'Y 243, 25I-52 (2014) (discussing "hostile unit climates" in the Canadian military and the lack of decisive response by commanders).

79. See New York v. U.S. Dep’t of Commerce, 315 F. Supp. 3d 766, 795 (S.D.N.Y. 2018).

80. Regents of Univ. of Cal. v. U.S. Dep't of Homeland Sec., 908 F.3d 476, 491 (9h Cir. 2018); Ramos v. Niclsen, 336 F. Supp. 3d 1075 (N.I). Cal. 2018).

81. See Chesney, supra note 7, at 1374. 
available to get the facts. Confronting this asymmetry in information, courts are reluctant to second-guess the executive branch. ${ }^{82}$

In rescission cases, there is reason to relax concerns about institutional competence. In such cases, an administration has already used its factfinding capabilities to explore a problem, canvas alternatives, and reach a decision. In the administrative state, few decisions are made overnight. Rather, administrators often-particularly in the national security arena-have to participate in an interagency process that jettisons bad ideas and refines good ones. ${ }^{83}$ Moreover, because an agency often embodies many schools of thought and also brokers the interests of external stakeholders, an action that is actually announced and implemented - even in part - reflects a critical mass of disparate actors. ${ }^{84}$ In addition, many actors and stakeholders have their own pet projects, which compete with the action at issue. An action that becomes official policy has to compete successfully for agency attention with many other compelling alternative projects. Because of these obstacles, some strong arguments have to favor a proposal that reaches the status of an announced and implemented decision.

Consider in this regard the inclusive transgender policy announced in 2016 by Secretary of Defense Ashton Carter. ${ }^{83}$ That policy was supported by a lengthy report from the Rand Corporation, a longtime consultant to

82. When Congress delegates power to an agency to decide an issue, that delegation provides an additional basis for deference. See Trump v. Hawaii, 138 S. Ct. 2392, 2418 (2018); see also Peter Margulies, Advising Terrorism: Material Support, Safe Harbors, and Freedom of Speech, 63 HAstings L.J. 455, 457 (2012) (explaining the Court's willingness to defer to Congress's restrictions on material support to foreign terrorist groups, even when statute affected content of speech).

83. See Robert F. Bauer, The National Security Lawyer, In Crisis: When the "Best View" of the Law May Not Be the Best View, 31 GEO. J. LEGAL ETHICS 175, 239-40 (2018) (discussing issue of the process regarding the provision of legal advice to the executive branch); see also Mary DeRosa, National Security Lawyering: The Best View of the Law as a Regulative Ideal, 31 GeO. J. LeGAL ETHICS 277, 291-92 (2018) (discussing "Lawyers Group[s]" that customarily met on an interagency basis to discuss national security issues); Christopher Fonzone \& Dana Remus, What About When the Best View Is the Best View?, 31 Geo. J. Legal EtHics 305, 315-18 (2018) (discussing elaborate structures for dialogue and accountability within the executive branch); Ingber, supra note 37; see also Daphna Renan, Presidential Norms and Article II, 131 HARV. L. REV. 2187, 2206-08 (2018) (discussing formal and informal protocols and procedures within executive branch). See generally JACK GOLDSMITH, POWER AND CONSTRAINT: THE ACCOUNTABLE PRESIDENCY AFTER 9/11 (2012) (discussing the actions taken by the executive branch after 9/11).

84. See Ingber, supra note 37, at 143; Neal Kumar Katyal, Internal Separation of Powers: Checking Today's Most Dangerous Branch from Within, 115 Y ALE L.J. 2314, 2417 (2006); Rao, supra note 37, at 275; Mila Sohoni, The Administrative Constitution in Exile, 57 WM. \& MARY L. REv. 923, 939-40 (2016); cf. Aziz Z. Huq \& Jon D. Michaels, The Cycles of Separation-ofPowers Jurisprudence, 126 YALE L.J. 346, 408 (2016) (suggesting cycles in judicial willingness to rely on the executive branch's internal checks).

85. See Press Release, Dep't of Def., supra note 66. 
the government on a broad spectrum of issues, including many former government officials. ${ }^{86}$ Secretary Carter's decision to relax the longtime ban on transgender personnel's accession to or retention in the military also had to win approval from the various services and the Joint Chiefs of Staff. To be sure, this is not a formal requirement in the U.S. Department of Defense (the DoD), given the constitutional imperative of civilian control. ${ }^{87}$ Some dissent is certainly possible, and was indeed actually present in the transgender inclusion context. ${ }^{88}$ Nevertheless, as a practical matter, promulgating a measure over the assiduous opposition of a majority of senior general officers would be difficult, especially given the need for the military to implement an inclusive directive in addition to the prospect of hostile senior officers reaching out to allies in Congress and the media. ${ }^{89}$ Such opposition does not occur frequently and is fraught with peril for its participants, ${ }^{90}$ but the prospect of such opposition will often stymie proposals that lack a coherent rationale, compelling evidence, and an elevated spot in senior political appointees' priorities. A court reviewing a rescission of that agency measure has some degree of confidence that the measure slated for rescission was at least not outlandish, rife with unintended consequences, or wholly lacking in political or bureaucratic support. ${ }^{91}$

86. See generally Agnes Gereben Schaefer et Al., Rand Corp., Assessing the

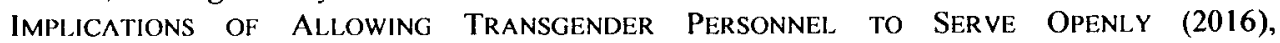
https://www.rand.org/pubs/research_reports/RR 1530.html [https://perma.cc/4YJ7-Z2WA] (assessing the U.S. Department of Defense's policy regarding transgender persons serving in the military while undergoing transition-related treatment).

87. See Deborah N. Pearlstein, The Soldier, the State, and the Separation of Powers, 90 TEX. 1. REV. 797, 801 (2012) (analyzing inherent problems with civilian controls over the military).

88. See U.S. DEP'T OF DEF., REPORT AND RECOMMENDATIONS ON MILITARY SERVICE BY TRANSGLNDLR PERSONS 44 (2018) (citing views of senior general officers approving the rollback of Secretary Carter's policy, supporting the inference that at least some senior generals had disagreed with Secretary Carter's change).

89. See Pearlstein, supra note 87 , at 799-800 (discussing the pervasive involvement of the military in defense policy formation and the political interactions of some senior military leaders).

90. Id. at 799 n.7 (discussing the firing of General Stanley McChrystal for publicly disagreeing with official policy and casting aspersions on senior civilian officials).

91. Of course, such characterizations may also be true of rescissions. $C$. Trump v. Hawaii, 138 S. Ct. 2392, 2404 (2018) (crediting the "worldwide review" with giving rise to the third iteration of President 'Irump's travel ban). Ilowever, decisions in the Trump Administration often do not receive such vetting, at least when they are of personal interest to President Irump. See, e.g., James Goldgeier \& Iilizabeth N. Saunders, The Unconstrained Presidency: Checks and Balances Froded long Before Trump, loORlilin Ali. (Aug. 13, 2018), htlps://www. foreign affairs.com/articles/2018-08-13/unconstrained-presidency?utm_campaign=reg_conf_cmail\& utm_medium=newsletters\&utm_souree=fa_registration |https://perma.ce/13V7I,-I I.6B| ("In the age of Donald l'rump, it often fecls as though one individual has the power to chart the United States" course in the world all by himself."). In these siluations, senior advisors are often relegated 
Similarly, a policy already in place often has backing in Congress. Admittedly, that backing may not be sufficient to result in an express codification of the policy. Moreover, some legislators may oppose the policy and do so vocally. However, many policies so enacted will have firm bipartisan support. ${ }^{92}$ That increases the likelihood that such policies will eventually take their place in Justice Robert Jackson's familiar typology as measures taken against a backdrop of congressional silence. ${ }^{93}$ In the short term, Congress's response may not move the Youngstown needle sufficiently to establish the prior policy's lawfulness. However, the absence of clear, consistent, and substantial congressional opposition to an announced policy does at least provide some indicia that the policy has wide support.

\section{Threshold Rescission and the Importance of Means-Ends Scrutiny}

Because of these factors, a threshold rescission should be subject to intermediate scrutiny. Under intermediate scrutiny, courts will determine if a given measure is "narrowly tailored to serve a significant governmental interest." $"$ This test of fit between means and ends will ensure that adequate deliberation supports threshold rescissions.

Requiring a fit between ends and means encourages deliberation and guards against the short-term thinking that distressed the Framers. ${ }^{95}$ The Framers were well-acquainted with the thought of Aristotle and other classical theorists ${ }^{96}$ who regarded means-ends fit as integral to practical judgment. ${ }^{97}$ As Alexander Hamilton observed, courts using practical

to triage and improvisation, stopping some highly imprudent moves and delaying others, while of necessity permitting the implementation of some decisions that a more comprehensive vetting process would catch. See Peter Margulies, Legal Dilemmas Facing White House Counsel in the Trump Administration: The Costs of Public Disclosure of FISA Requests, 87 FORDHAM L. REv. 1913, 1929-31 (2019). In any case, under the model proposed in this Article, it seems reasonable to believe that the proof is in the pudding: If a threshold rescission passes means-ends scrutiny, a court should uphold it. If not, a court should restore the status quo prior to the rescission.

92. See Johnson, supra note 33 , at 368 (discussing DACA's bipartisan congressional backing).

93. See Youngstown Sheet and Tube Co. v. Sawyer, 343 U.S. 579, 635-38 (1952) (Jackson, J., concurring).

94. See Packingham v. North Carolina, 137 S. Ct. 1730, 1736 (2017) (quoting McCullen v. Coakley, 134 S. Ct. 2518, 2534 (2014)).

95. See The Federalist No. 78 (Alexander Hamilton) (suggesting that judicial review could temper influence of short-term "ill humors" on the political branches).

96. Cf. Hannah Arendt, ON Revolution 203 (Penguin Books 1990) (1977) (noting the Framers' affinity for classical thought).

97. See Aristotle, Nichomachean Ethics 152 (Martin Ostwald trans., The Bobbs-Merrill Co., Inc. 1962) ("[T] oneself is ... typical of ... practical wisdom ... . This is shown by the fact that we speak of men as having practical wisdom in a particular respect ... when they calculate well with respect to 
judgment to assess constitutionality also yield vital ex ante benefits for political officials, prodding them to tailor proposed actions to forestall judicial invalidation. $^{98}$

As an example of means-ends scrutiny that nominally only required a "rational relationship" between means and ends but was in fact more robust, consider City of Cleburne v. Cleburne Living Center. ${ }^{99}$ In Cleburne, the Supreme Court struck down a local ordinance that mandated that operators of a proposed group home for persons with mental retardation receive a special permit. ${ }^{100}$ The Court discerned a lack of means-ends fit in the ordinance because the town's method for fulfilling its goals ignored a great deal of activity that appeared inconsistent with those goals. For example, the town justified requiring a special permit by citing increased traffic and congestion. ${ }^{101}$ However, the ordinance did not require a special permit requirement for other uses, including fraternity houses, dormitories, and hospitals. ${ }^{102}$ This gap in the special permit scheme showed that the town had not tailored means to goals.

The Court has also employed robust means-ends scrutiny in the context of citizenship law, closer to the national security and foreign relations focus of this Article. In Sessions v. Morales-Santana, ${ }^{103}$ the Court struck down a provision that favored mothers over fathers regarding citizenship acquired at birth by a child born out of wedlock

some worthwhile end ...."); see also Peter Margulies, Bans, Borders, and Sovereignty: Judicial Review of Immigration Law in the Trump Administration, 2018 MICH. ST. L. REv. 1, 18-19 (2018) (discussing the Framers' view of means-ends scrutiny and applying that approach to immigration law).

98. See THE FEDERALIST No. 78 (Alexander Hamilton) (noting that the prospect of judicial revicw will encourage political actors to "qualify"-i.e., limit-their efforts to enact unjust measures).

99. 473 U.S. 432 (1985); see Peter Margulies, The Travel Ban Decision, Administrative Law, and Judicial Method: Taking Statulory Context Seriously, 33 Gto. IMmiGR. L.J. 159, $178-$ 79 (discussing flaws in the Supreme Court's use of Cleburne in Trump v. Hawaii to justify upholding President Trump's travel ban). Katic liyer has written extensively on the complexities and contradictions of the Court's tiered system of review, under which nominally minimal review can sometimes be actually robust, as in Cleburne, and lack of proof of intent can stall heightened scrutiny. See generally, e.g., Katic R. Eyer, Animus Trouble, 48 STLTSON L. REv. 215 (2019) (arguing that progressives ought to be concerned about scholarly efforts to systematize the animus doctrine).

100. Trump v. Hawaii, 138 S. Ct. 2392, 2420 (citing City of Cleburne v. Cleburne Living Cir.. 473 U.S. $432,448-50(1985))$.

101. Cleburne, 473 U.S. at 450.

102. Id.

103. $137 \mathrm{~S} . \mathrm{Ct} .1678$ (2017); $c$. Kristin $\mathrm{A}$. Collins, Equality. Sovereignty, and the Family in Morales-Santana. 131 IIARV. L.. Rl:v. 170. 204-06 (2017) (arguing that the decision could set the stage for rethinking judicial deference on immigration); Margulies, supra note 97, at 19-21 (analyring Morales-Santana). 
abroad to a U.S. and foreign national. ${ }^{104}$ According to Justice Ruth Ginsburg, who wrote for the Court, the provision's lack of means-ends fit was fatal. ${ }^{105}$ If Congress wished to ensure that a child born abroad was "American in character" and thus merited citizenship, ${ }^{106}$ requiring prolonged U.S. presence by the parent would show the parent's investment in the child's American identity. ${ }^{107}$ Nevertheless, mandating prolonged U.S. presence for a U.S. citizen father but not a U.S. citizen mother "scarcely serve[s] the posited end." 108 In the absence of meansends fit, the Court struck down the acquired citizenship provision. ${ }^{109}$

However, in Trump v. Hawaii, the Court's means-ends review was far more deferential. ${ }^{10}$ In an opinion by Chief Justice John Roberts, the Court upheld President Trump's travel ban on certain majority-Muslim countries. ${ }^{11}$ Illustrating its lack of means-ends fit, the ban covered a range of individuals, including young children, whose entry into the United States could not possibly endanger the national security of the United States. ${ }^{12}$ Moreover, the ban cited the need to ensure appropriate identity management steps by the countries that the ban covered, even though some of those countries had strong track records in this area and over one hundred countries with poor records were not covered by the ban. ${ }^{113}$

104. See Morales-Santana, 137 S. Ct. at 1682, 1698, 1700-01.

105. Id. at 1690 ("The defender of legislation that differentiates on the basis of gender must show 'at least that the [challenged] classification serves important governmental objectives and that the discriminatory means employed are substantially related to the achievement of those objectives." (alteration in original) (quoting United States v. Virginia, 518 U.S. 515, 524 (1996))).

106. Id. at 1692 (quoting Hearings on H.R. 6172 before the H. Comm. on Immigration and Naturalization, 76th Cong. 431, 426-27 (1939)). See generally Kristin A. Collins, Illegitimate Borders: Jus Sanguinis Citizenship and the Legal Construction of Family, Race, and Nation, 123 YALE L.J. 2134 (2014) (discussing the constitutionality of immigration statutes governing the citizenship status of children born to American parents outside the United States that discriminate between mother and father).

107. Morales-Santana, $137 \mathrm{~S}$. Ct. at 1692 (rooting presence requirements in reasonable congressional desire to ensure that a U.S. citizen parent could "counteract the influence of the alien parent"); $i d$. at 1695 (assuming that Congress wished to "ensur[e] a connection between the foreign-born nonmarital child and the United States").

108. Id. at 1695 .

109. Id at 1701.

110. See Trump v. Hawaii, 138 S. Ct. 2392, 2420 (2018).

111. Id. at 2423. The ban also extended to North Korea, which does not let its nationals leave its own territory, and Venezuela-the latter restriction dealing only with members of the Maduro regime and their family members and associates. See id. at 2405-06.

112. See id. at 2445 (Sotomayor, J., dissenting).

113. See id. at 2404 (majority opinion); $c f$. Margulies, supra note 97, at 63-65 (discussing the travel ban proclamation's weak links between the ban and interests such as identity management); Margulies, supra note 99, at 18 (analyzing the decision's loose conception of 
The approach this Article takes requires a more robust brand of means-ends scrutiny than the Court employed in the travel ban case. Within that framework, an agency can argue that the rescission serves administrative constitutionalism by fulfilling the government's responsibility, preserving the separation of powers, or protecting other groups' rights. However, a reviewing court should carefully scrutinize such claims.

\section{The Trump Administration's New RESTRICTIONS ON Transgender Military SERvice: Of False Starts AND GRANDFATHERED ORPHANS}

The Trump Administration's restrictions on transgender military service roll back an expansion of transgender access and retention set in motion under the Obama Administration. In grandfathering in certain transgender service members, the new restrictions actually incorporate some of the same elements proposed in this Article. Moreover, courts assessing the new restrictions will need to acknowledge the deference that military judgments have traditionally received. ${ }^{14}$ Nevertheless, as Section II.A shows, some of the new restrictions fail to comply with the Constitution.

\section{A. Secretary Carter's Constitutionalist Vision}

Secretary Carter's inclusive policy incorporated both a vision of the Constitution and a path to implementing transgender inclusion that provided sound guidance to commanders. ${ }^{15}$ Justifying the policy, Secretary Carter stated the commitment to inclusion in terms of military effectiveness. As Secretary Carter asserted, the U.S. military needs "all available talent in order to remain the finest fighting force the world has ever known." 16 The military's "mission ... to defend this country" requires taking down "barriers unrelated to a person's qualification to

mcans-ends (it); David Bier, Travel Ban Is Based on Executive Whim, Nol Objective Criteria, CATO INST. (Oct. 9, 2017), https://www.cato.org/blog/travel-ban-based-executive-whim-notobjective-criteria |https://perma.ce/5PZC-HL8V| (describing the decision's means-ends fit).

114. See, e.g., Rostker v. Goldberg, 453 U.S. 57, 66 (1981); Doe 2 v. Shanahan, 917 F.3d 694, 719-20 (I.C. Cir. 2019) (Williams, J., concurring) (explaining the rationale for judicial deference).

115. Secretary Carter's initiative called for phasing in the new rules on the accession of transgender individuals to the military. See Press Release, Dep't of Def., supra note 66. These rules were supposed to take effect in 2017. See id. President Trump first delayed implementation of the new rules and then rescinded them after issuance of the 2018 Defense Report and Secretary Mattis's recommendations. See Memorandum from Donald J. Trump, supra note 2.

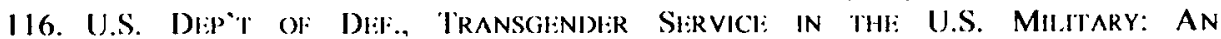
IMPIEMENTATION IIANDBBOOK 10 (2016) (emphasis added). 
serve." "117 The nod to equality here affirmed that inclusion is a fundamental value in the U.S. constitutional system; the military, as an integral part of that system, benefits from sharing those values. Indeed, in certain contexts, including racial integration, the military has been a leader, sending signals that the rest of society has followed. ${ }^{18}$

\section{Transgender Personnel Currently Serve in the Military}

Under Secretary Carter's initiative, responsibility and inclusion were not merely abstractions - they were pragmatic. As the Department of Defense Handbook noted, "[t]here are transgender Service members in uniform today." "I9 In other words, even if Secretary Carter had done nothing to ease restrictions on transgender accession and retention, the military would still confront challenges regarding the integration of transgender persons.

In addressing those challenges, Secretary Carter understood that prejudice against transgender persons is dynamic, not static. As the military has discovered with its easing or elimination of restrictions based on race, gender, and sexual orientation, attitudes can broaden "over time." 120 A pragmatic understanding of human institutions acknowledges the inevitability of change.

\section{Responsibility and Guidance in the Carter Policy}

Secretary Carter's policy was also mindful of both the government's responsibilities and the rights of others. Under Carter's policy, rules for accession maintained substantial limits on prospective transgender service members. Since the rules required that a new recruit be stable and without significant clinical distress for eighteen months, ${ }^{121}$ Carter's criteria screened out a substantial cohort of transgender persons who had experienced gender dysphoria within that period. Under the American Psychiatric Association's compendium of clinical wisdom, the Diagnostic and Statistical Manual (DSM-5), "clinically significant distress" is a key symptom of gender dysphoria, which refers to a "marked incongruence" between expressed and assigned gender. ${ }^{122}$

117. Id. at 7 .

118. See AGNES GEREBEn SCHAEFER ET AL., supra note 86, at 44; Knowles, supra note 63; Joseph Landau, Presidential Constitutionalism and Civil Rights, 55 WM. \& MARY L. REv. 1719, 1762 (2014) (noting the Obama Administration's successful effort to repeal the military's "Don't Ask, Don't Tell" policy limiting gay and lesbian service).

119. U.S. DEP'T OF DEF., supra note 116 (emphasis added).

120. AGNES GEREBEN SCHAEFER ET AL., supra note 86, at 44.

121. U.S. DEP'T OF DEF., supra note 116, at 40.

122. Marty Lederman, Untangling the Issues in the "Transgender in the Military" Litigation, JUST SECURITY (Jan. 7, 2019) (emphasis omitted) (quoting AM. PSYCHIATRIC Ass'N, 
Screening out prospective recruits who had exhibited significant distress within eighteen months of accession barred candidates whose conflicts between experienced and assigned gender could have impaired their ability to help accomplish the military's mission.

The Carter approach also entailed detailed guidance for commanders. This attention to detail began with the Rand report that provided the initial support for Carter's initiative. While the 2018 Department of Defense Report (the 2018 Report) partially rolling back Carter's policy faulted Rand for a misleadingly rosy view of the literature on other militaries' experience, ${ }^{123}$ the Rand report's authors actually acknowledged shortfalls in the practice of America's allies, including Canada. ${ }^{124}$ The Department of Defense Handbook implementing Carter's changes did not stint on details. It included a cornucopia of hypotheticals that provided sensible guidance to commanders, particularly on managing accommodations for transgender persons that might touch on countervailing rights such as the privacy and dignity of non-transgender service members. ${ }^{2}$

\section{Taking Statistics Seriously: Low Base Rates for Transgender Personnel}

Lastly, the Carter policy relied on estimated low base rates for transgender recruits to discount both monetary costs and disruption in deployments that the military would experience because of transgender exclusion. ${ }^{126}$ Rand used estimates of the incidence of transgender status in the military that pegged that number as higher than it would be in the

Diagnostic and Statistical Manual of Mental Disorders (DSM-5) (5th ed. 2013)), https://www.justsecurity.org/62128/untangling-issues-transgender-military-litigation/ [https:// pcrma.cc/81EC-5DMJ]. Marty Lederman has authored an exceptionally insightful and comprehensive study of differences and overlaps between the Carter and Mattis policies that explains the core treatment and diagnostic concepts. See id.

123. See U.S. DEP'T OF DEF., supra note 88, at 40.

124. See Agniss Gikiiben SCHAlFFer lit Al., supra note 86, at 62-63 (noting that a Canadian study documented persistence of harassment of transgender service members); id. at 63 (noting that Canada's initial policy was "too vague and lacked sufficient details" and reporting that the newly revised Canadian policy had garnered positive responses).

125. See, e.g., U.S. DIEP'T OF DII\%, supra note 116, at 63 (providing guidance on administering a swim test involving fully transitioned male service member who retained female secondary sexual characteristics, including the sensible suggestion that everyone wear a shirt). In addressing shower protocol, the Department of Defense l landbook recommended common-sense steps such as installing shower curtains and placing towel and clothing hooks within individual stalls as well as staggering shower times. $l d$. at 60-61.

126. ACINI:S GI:RIIBIIN SCIIAIIIIIR IIT AL.., supra note 86, at 34-35. 1 base rate is the overall percentage that a particular phenomenon comprises in a particular population. See Drew Boyd, Innovation and the Base Rate, PSYCHOL. TOI)AY (July 11, 2013), https://www.psychology today.com/us/blog/inside-the-box/201307/innovation-and-the-base-rate /https://perma.cc/8TAP6RP'/. 
general population. ${ }^{127}$ Based on that extreme figure-which is still low overall-Rand estimated that the net increased cost of transition-related health care for the entire U.S. military would be a maximum of $\$ 8.4$ million. ${ }^{128}$

That figure translates into an infinitesimal increase in the military's overall health care costs. Estimating the relative increase in health care costs for a large entity like the U.S. military also requires estimating the total health care costs of that entity. Based on 2015 estimates, the U.S. military spends $\$ 6.2$ billion on health care annually, including expenses related to mental health, pregnancy of service members and their dependents, and a host of other long- and short-term conditions. ${ }^{129}$ Rand's worst-case projection of transition-related health costs $-\$ 8.4$ millionwould represent a paltry $0.13 \%$ of the military's total health care budget. ${ }^{130}$ Put another way, if an individual paid a health insurance premium of $\$ 1,000$, the added coverage of transition-related care would cost that subscriber an additional $\$ 1.30$.

The same focus on base rates illustrates the minimal effect an inclusive transgender policy would have on deployment. Of course, the ability to deploy readily is a central attribute for an effective military. A key metric for measuring disruption in employment is the labor year: the time spent on work by an employee annually. As a large entity, the U.S. military has a very high total for aggregate labor years: 1.2 million. ${ }^{131}$ As of 2015, the active duty component of the U.S. Army alone already had 50,000 soldiers who were not deployable due to medical, legal, and administrative factors. ${ }^{132}$ That total amounted to $14 \%$ of the active duty Army, and 5,300 labor years. ${ }^{133}$ In other words, approximately one out of seven active duty Army personnel was unavailable to deploy for all or a significant part of the preceding year. In contrast, even extreme estimates of labor years lost because of transition-related medical treatment amounted to no more than a total of forty-three, and could be as few as eight. ${ }^{134}$ In a small number of "unique military occupation[s]," such as a fighter pilot that might involve "frequent, unpredicted mobilizations," a high incidence of serious medical procedures would in fact disrupt

127. AGNES GEREBEN SCHAEFER ET AL., supra note 86, at 35 (using the higher figure because the military is disproportionately male and male-to-female transition is more common in the general population).

128. Id. at 36 .

129. Id.

130. Id.

131. Id. at 42 .

132. Id. at 46.

133. Id at $46-47$.

134. Id. at 42 (noting this was in part because only a small number of transgender service members actually undergo medical procedures that would affect deployability). 
deployment. ${ }^{135}$ If everyone in an aviation unit required a transfer, that would obviously affect combat readiness. But the low incidence of transgender personnel reduces this risk to virtually zero.

The high incidence of nondeployability in the U.S. military independent of transition treatment highlights a final facet of responsibility alluded to earlier: transgender individuals already serve in the military and have done so for a long time. However, under the transgender ban they could not do so openly. As a corollary to this covert existence, transgender service members were at greater risk for suicide and mental illness. ${ }^{136}$ Barring treatment for transitions caused human tragedies and increased costs for conditions caused by the absence of treatment and acceptance. Secretary Carter acknowledged these human and financial costs.

\section{B. The Mattis Policy's Constitutionalist Response}

The 2018 Mattis policy's administrative constitutionalist vision did not adequately support its partial rescission of Carter's policy. Because the rescission is partial, not plenary, further unpacking of the 2018 policy is useful. Several of the 2018 departures from the Carter policy fail the test of means-ends fit, including the policy's refusal to allow accommodations in bunking, bathroom use, and showering for service members who have received a diagnosis of gender dysphoria after the effective date of the 2018 policy. ${ }^{137}$ However, the Mattis policy appropriately grandfathered in current service members who have already received a diagnosis of gender dysphoria in reliance on the Carter policy, including those who had planned medical procedures. ${ }^{138}$

Moreover, the Mattis policy did not restrict accession and retention of all transgender individuals because it grandfathered in certain medically transitioning personnel and was open to individuals who identified with a gender other than their assigned one but did not suffer from gender dysphoria. ${ }^{139}$ In addition, one element of the Mattis policy's change in accession criteria - extending from eighteen to thirty-six months the time that candidates with gender dysphoria must be stable prior to accessionis a difference from the Carter policy in degree, but not in kind. For this reason, this Article concludes that courts should disaggregate the

135. Id. at 43.

136. Id. at $9-10$.

137. See U.S. DI:P'T OI: DI:1., supra note 88, at 42.

138. See Doe 2 v. Shanahan, 917 F.3d 694, 700 (D.C. Cir. 2019) (Wilkins, J., concurring) (noting that the Mattis policy was not a total ban on transgender accession and retention and detailing its differences from President Trump's original tweet on this subject).

139. Id: see also id. at 701 (agrecing that Mattis policy did not constitute a total transgender ban); lederman, supra note 122 (citing to the Shanahan decisions). 
components of the Mattis policy and separately review their respective means-ends fit.

Before disaggregating those components, it is useful to more fully discuss the Mattis policy's reasoning, as articulated in the 2018 Report. Regarding its refusal to allow accommodations in bunking, bathroom use, and showering, the 2018 Report invoked the "reasonable expectations of privacy" of non-transgender service members and the DoD's responsibility to ensure "good order and discipline." 140 The 2018 Report stated that the Carter policy and the Rand report supporting that policy unduly discounted the "conflicting interests" that an inclusive transgender policy would set in motion, as well as the "significant effort required of commanders" to address those issues. ${ }^{141}$ These effects would impair unit cohesion, "degrad[ing] an otherwise highly functioning team." ${ }^{\text {"142 }}$ Moreover, the 2018 Report declared, the Rand report's citation to positive experiences with transgender inclusion in other militaries, such as Canada's, had failed to acknowledge the problems remaining in those entities. ${ }^{143}$ Finally, the 2018 Report asserted that the Carter policy failed to adequately address the "[d]isproportionate" medical costs of inclusion and the increased risk of suicidal behavior. ${ }^{144}$

As a first step in addressing these concerns, the 2018 Report echoes the Carter policy by imposing limits on accession for unstable candidates. The Carter policy required a showing of eighteen months of stability prior to accession, while the 2018 policy doubles that amount to thirty-six months. In both cases, the stability criterion is designed to bar individuals most likely to impose costs and present challenges to commanders. The doubling of time in the Mattis policy is a difference in degree only. Because the stability requirement will screen out many individuals, the Carter and Mattis policies differ principally in how they handle the residual cases.

\section{The Mattis Policy's Partial Rollback}

The Mattis policy also does not restrict all transgender individuals going forward. Outside of the grandfathered group, its principal impact is on those with gender dysphoria and on persons seeking to join the military who have already fully transitioned through medical treatment or otherwise. The DSM-5 of the American Psychiatric Association recognizes persons as transgender if they feel a need to express

140. See U.S. DEP'T OF DEF., supra note 88, at 36.

141. Id. at 38 .

142. Id.

143. Id. at 40.

144. Id. at 41 (discussing medical costs) (emphasis omitted); see id. at 21 (discussing suicide risk). 
themselves in a gender other than their assigned gender, even if that feeling does not rise to the level of gender dysphoria. ${ }^{145}$ The 2018 policy would allow persons with that need to serve, as long as they could comply with the standards imposed on their assigned gender. ${ }^{146}$ Because the 2018 policy does not bar accession or retention of all transgender individuals, under the traditional equal protection approach courts would employ only rational basis review, which the policy could most likely pass. However, the more rigorous review proposed in this Article would lead to a different result, at least for certain aspects of the Mattis policy.

\section{The Mattis Policy and Means-Ends Fit}

Significant parts of the Mattis policy lack means-ends fit. These include the bar on retention of individuals who in the future require either transition-related medical services or accommodations in bunking, bathroom use, and showering. Another vulnerable component is the bar on accession of individuals who have already completed a medical transition. These contexts provide the clearest contrasts to the Carter policy.

Lack of means-ends fit is a problem for the 2018 Mattis Policy's bar on retention of individuals requiring future medical procedures. The 2018 Report cites current data on the costs of such procedures to support its recommended changes to the Carter policy. ${ }^{147}$ While the data included in the 2018 Report indicates a cost increase due to inclusion, that data reveals less than meets the eye. The "headline" in the 2018 data is a $300 \%$ increase in "medical costs" for service members with gender dysphoria. ${ }^{148}$ But the 2018 Report fails to provide crucial context, such as countervailing costs, low base rates for transgender individuals in the military, low absolute costs, and very low relative costs of transgender medical treatment, as compared with the military's overall medical expenditures. $^{149}$

An assessment of countervailing costs highlights a point that the Carter policy takes as a fundamental premise but the Mattis policy downplays: transgender people - even apart from the group wisely grandfathered in under the new policy - are already in our military and

145. See Lederman, supra note 122 (outlining the $\Lambda$ merican Psychiatric $\Lambda$ ssociation's recognition of transgender persons' need to express themselves in a gender other than their assigned gender at birth).

146. See Doc 2 v. Shanahan, 917 I:3d 694, 699-700 (D.C. Cir. 2019) (Wilkins, J., concurring).

147. U.S. Di:P OF Di:l., supra note 88, at 41 . Waivers are also possible, but the military will presumably be sparing in granting them. See id. at 42 .

148. Id. at 41 .

149. See supra text accompanying notes 126-130. 
will be there in the future, experiencing needs that the military will have to address, one way or another. The 2018 Report's $300 \%$ quote fails to specifically address the countervailing costs of both medical and nonmedical services delivered to persons already in the military who are transgender but have not yet acknowledged this publicly. Those individuals also seek treatment for a range of conditions, including depression, suicide attempts and ideation, and medical issues that serve as proxies for transgender treatments. ${ }^{150}$ There is no indication that the 2018 Report factored in these countervailing costs avoided by inclusion.

Indeed, the 2018 Report's approach to the issue of suicide among transgender individuals demonstrates its failure to address the problems of transgender individuals who already serve. The Rand report demonstrates that suicide is a heightened risk for individuals who do not serve openly. ${ }^{151}$ Studies show that the absence of acceptance is a prime contributor to suicide in this cohort. ${ }^{152}$ Restrictive policies in the military are another link in that chain. Suicide among transgender individuals is not a new problem ushered in by inclusion; it is an old problem that restrictive policies exacerbate. The Carter policy acknowledged this concern; the 2018 Report unduly discounted it.

The 2018 Report's failure to fully address the problems of alreadyserving transgender personnel also undermines the recommended bar on retention of individuals who require accommodations in bunking, bathroom use, and showering. Here, too, the 2018 Report fails to acknowledge that base rates for such issues will be quite low, and that measures such as the thirty-six-month stability requirement for accession will drive these rates down even further. A complete report would have directly compared these low levels of disruption with the higher levels of treatment for depression and other conditions that covert transgender personnel already require, which also disrupt unit cohesion and combat readiness. In addition, the 2018 Report should have fully acknowledged the very specific guidance on privacy that Secretary Carter provided in the Department of Defense Handbook, including recommendations on subdividing showers and staggering shower times. ${ }^{153}$ While the 2018 Report warns of significant effort expended by commanders, the

150. See Agnes Gereben SChaEFER ET AL., supra note 86, at 9-10, 33-34 (discussing the range of costs that transgender inclusion would markedly reduce and providing the example of an individual who sought and received breast reduction due to back pain as a proxy for treatment attributed to gender transition).

151. Id. at $9-10$.

152. See Raymond P. Tucker et al., Current and Military-Specific Gender Minority Stress Factors and Their Relationship with Suicide Ideation in Transgender Veterans, 49 SUICIDE \& LiFE-THREATENING BeHAV. 155, 155-56 (2019).

153. See supra notes $137-140$ and accompanying text. 
straightforward advice in the Department of Defense Handbook answers most reasonable questions. ${ }^{154}$

For the same reasons, the 2018 Mattis policy's bar on accession of already-transitioned candidates fails intermediate scrutiny. This policy may serve the military's legitimate "interest in uniformity." 155 In this sense, the 2018 policy echoes earlier case law deferring to military judgments about qualifications and apparel. ${ }^{156}$ However, given the importance of contributions that transitioned transgender individuals can make and the costs of the old ban, those judgments should not overcome the force of Secretary Carter's shift to a new paradigm.

In sum, disaggregation is a useful exercise for evaluating the 2018 Mattis policy. The thirty-six-month stability requirement prior to accession survives intermediate scrutiny. The ban on accession of completely transitioned candidates fails, as do the retention bars for those service members who require future accommodations or medical treatment. While the 2018 policy helpfully grandfathers in service members who have already planned medical treatments and allows the accession and retention of persons without gender dysphoria, the remaining Mattis restrictions lack means-ends fit. They may be sufficient under the relaxed standard that customarily applies in the absence of suspect or quasi-suspect classifications. However, under the approach taken here, those restrictions fail.

154. The 2018 Report's criticism of Carter's policy on accommodations relied on isolated cases and misinterpretation of earlier guidance. The authors of the 2018 Report cited one case in which female members of a unit had complained about a showering accommodation for a transgender service member, who in turn had filed a complaint stating that the commander had not respected the transgender service member's rights under the new policy. See U.S. DEP'T OF Dex., supra note 88, at 37. Such bumps in the road are common for implementation of any new paradigm. While some resistance to change is a given in the short term, resistance is not a static phenomenon; it can change over time. $\Lambda$ s Secretary Carter's Department of Defense Handbook reflected, a clear response from commanders would greatly ease this process, as it did for the other changes that the military has managed in the last seventy-five years, including integration based on race, gender, and sexual orientation. See AGNIS GERIBBEN SCHAEFIR ET AL., supra note 86, at 44.

The 2018 Report also incorrectly asserted that the Rand report failed to note that foreign militaries such as Canada's did not provide sufficient guidance. See U.S. DEP'T OF: DEF., supra note 88, at 40-41. In fact, the Rand report expressly noted this problem. See AGNLS GIBREBLEN SCIAI:FI:R I:T AI..., supra note 86, at 54 (noting that Canada's initial policy "d|id| not . . provide guidance" on balancing transgender service members' need for accommodation and others' privacy rights). Carter's guidance on accommodations was a response to the initial problems that Canada's experience revealed. 'The 2018 Report's misinterpretation of earlier documents is one reason to accord it less deference than courts have traditionally employed.

155. U.S. DI:P’T OI: Dill., supra note 88, at 38.

156. See, e.g., Goldman v. Weinberger, 475 U.S. 503, 507-10 (1986) (upholding military regulations requiring uniformity in headgear that, inter alia, barred wearing of a yarmulke by an observant Jew who served as a elinical psychologist on Air liorce base). 


\section{The Census Citizenship Question as a Threshold Rescission}

Commerce Secretary Wilbur Ross's attempt to include a citizenship question on the 2020 census also counts as a threshold rescission. While the Secretary of Commerce has broad discretion in questions surrounding the census count, ${ }^{157}$ the selection of questions is nonetheless part of the constitutional obligation of completing the census. ${ }^{158}$ The census influences apportionment, which in turn affects the contours of political representation. Here, the government could not show the means-ends fit to satisfy intermediate scrutiny. ${ }^{159}$

\section{A. Past Practice on Asking the Citizenship Question}

In contrast with the military transgender policy, the policy that Secretary Ross rescinded did not start with President Obama. The Census Bureau last posed a citizenship question on the "short-form" census-the survey virtually everyone receives - in $1950 .^{160}$ The premise for this longtime practice of omitting the short-form census citizenship question warrants further explanation.

An accurate count includes the "whole number of persons." 161 The Department of Justice (DOJ) has consistently advised the Census Bureau that foreign nationals who are residents of the United States "must be included," regardless of their immigration status. ${ }^{162}$ Indeed, as DOJ attorney-now a noted constitutional law professor-David A. Strauss advised Congress in 1980, "[t]he drafters of the Fourteenth Amendment," which updated the census clause to reflect the freeing of enslaved people, "considered, and deliberately rejected, proposals that the apportionment of Representatives be based on the number of legal voters, or on the number of citizens. Historically, resident aliens of all varieties have been

157. Wisconsin v. City of New York, 517 U.S. 1, 2 (1996) (per curiam).

158. See U.S. CONST. art. I, $\S 2$, cl. 3.

159. The challenges to Secretary Ross's decision included both constitutional and APA claims. See Dep't of Commerce v. New York, 139 S. Ct. 2551, 2561 (2019). While the Court relied solely on the APA in upholding an injunction against the short-form census citizenship question, id. at 2574-76, this Article argues that the Court's APA analysis paralleled the constitutional arguments made in this section. See infra notes 204-08 and accompanying text.

160. Tamara Keith, Fact Check: Has Citizenship Been a Standard Census Question? NPR (Mar. 27, 2018, 8:02 PM), https:/www.npr.org/2018/03/27/597436512/fact-check-hascitizenship-been-a-standard-census-question [https://perma.cc/PNE6-MTHP].

161. U.S. ConsT. amend. XIV, $\S 2$.

162. See Census Equity Act: Hearing on H.R. 2661 Before the Subcomm. on Census \& Population of the H. Comm. on Post Office \& Civil Serv., 101st Cong. 43 (1989) (testimony of C. Louis Kinkannon, Deputy Dir., U.S. Census Bureau) [hereinafter Hearing on H.R. 2661]. 
included in the population figures on which the allocation of Representatives was based." 163

An inaccurate count of the "whole number of persons" would have significant collateral impacts. Suppose that a given method undermined "distributive accuracy"-a faithful comparative assessment of population in different sub-federal government subdivisions. ${ }^{164}$ That disparity could skew apportionment of seats in the House of Representatives and votes in the Electoral College, as well as state legislative seats. ${ }^{165}$ In addition, it could distort funding formulas used to allocate government money. Mistakes could also affect the giving of charitable foundations, the marketing strategies of corporations, and a long list of other activities. Those impacts merit care in the selection of questions that can affect participation rates.

From a historical perspective, census officials have not always viewed a citizenship question as clashing with such concerns. As Secretary Ross correctly observed, the government for well over a century asked a question about citizenship. ${ }^{166}$ However, the government stopped asking that question almost sixty years ago. ${ }^{167}$ Successive generations of census officials have argued on a bipartisan basis that such an inquiry would chill responses by undocumented noncitizens and others born abroad or related to foreign nationals in the United States. ${ }^{168}$

In preparation for the 1980 census, officials were gravely concerned about the prospect of "convincing undocumented immigrants that the

163. 1980 Census: Counting Illegal Aliens: Hearing on S. 2366 Before the Subcomm. on Energy, Nuclear Proliferation, \& Fed. Servs. of the S. Comm. on Governmental Affairs, 96th Cong. 96 (1980) (testimony of David A. Strauss). However, the Supreme Court has never decided this issuc.

164. Lyle Denniston, Does the Census Actually Count Everyone and Should It?, NAT'L CONST. CTR.: CONST. DAII.Y (Mar. 12, 2019), https://constitutioncenter.org/blog/does-the-censusactually-count-everyone-and-should-it [https://perma.cc/T8G9-L5LA].

165. Wisconsin v. City of New York, 517 U.S. 1, 5-6 (1996) (per curiam). The Supreme Court has held that "distributive accuracy" is vital to the census's role in apportionment. Id. at 20. In other words, a count featuring an overall error in estimating the United States population may not undermine the census's purpose if that count correctly states the population ratios between different states. That latter comparative ligure drives the apportionment process. See generally Nathanicl Persily, The Law of the Census: How to Count, What to Count, Whom to Count, and Where to Coun Them, 32 CARDO\%O L. RI:V. 755 (2011) (discussing principles applied by courts in census cases).

166. See Memorandum from Wilbur Ross, supra note 3, at 2; see also Dep't of Commerce v. New York, $139 \mathrm{~S}$. Ct. 2551, 2566-67 (2019) (discussing history of asking demographic questions on short-form census).

167. See Memorandum from Wilbur Ross, supra note 3, at 2.

168. See llearing on II.R. 266/. supra note 162, at 43-44 (observing that a citizenship question could "seriously jeopardize the accuracy of the census" because, due to concerns about answers assisting immigration enforecment, "immigrants may either avoid the eensus altogether or deliberately misreport themselves as legal residents"). 
census results would not be given to the Immigration and Naturalization Service officials for use in deportation proceedings." 169 This concern crystallized when a group favoring tougher immigration enforcement and limits on immigration, the Federation for American Immigration Reform (FAIR), sued the Secretary of Commerce over- the failure to ask a citizenship question. ${ }^{170}$ Finding for the Commerce Secretary, a threejudge district court panel observed that, according to census officials, a citizenship question would "inevitably jeopardize the overall accuracy of the population count" through a chilling effect on segments of the population anxious about "information being used against them" in immigration enforcement. ${ }^{171}$

In 1980 and in subsequent years, officials from the census bureau and other departments testified in Congress that a citizenship question would cause undocumented people-perhaps joined by naturalized citizens or those with undocumented or lawful resident relatives-to "misunderstand or mistrust the census and fail or refuse to respond." Focus groups assembled after Secretary Ross's decision to include the citizenship question provided strong evidence of mistrust expressed by minorities with immigrant ties, including persons of Hispanic, Chinese, Middle Eastern, North African, and Vietnamese heritage. ${ }^{173}$ Diminished response from these groups would then lead to losses in electoral representation and other benefits for states and cities with substantial proportions of undocumented and foreign-born individuals.

\section{B. The Citizenship Question and Means-Ends Fit}

While the strong discretionary component in determining appropriate census questions usually calls for a less exacting standard of review, ${ }^{174}$ under the approach taken in this Article, the departure from decades of practice and the collateral impacts just described warranted a closer look at the basis of Secretary Ross's decision. ${ }^{175}$ To do that, one must first consider the administrative constitutionalist rationale behind asking the citizenship question.

169. See Margo J. Anderson, The American Census: A Social History 234 (2d ed. 2015).

170. Fed'n for Am. Immigration Reform v. Klutznick, 486 F. Supp. 564, 565 (D.D.C. 1980).

171. Id.

172. See Hearing on H.R. 266I, supra note 162, at 53-54.

173. Michael Wines, Inside the Trump Administration's Fight to Add a Citizenship Question to the Census, N.Y. Times (Nov. 4, 2018), https://www.nytimes.com/2018/11/04/us/wilbur-rosscommerce-secretary.html [https://perma.cc/Y4FF-ZNS2].

174. Wisconsin v. City of New York, 517 U.S. 1, 19-20 (1996) (per curiam).

175. Historical experience has been important in judicial review of census decisions. $I d$. at 21; see also Franklin v. Massachusetts, 505 U.S. 788, 803-06 (1992) (discussing the relevance of historical practice). 
Secretary Ross's rationale for the change also centered on rights; for Secretary Ross, the putative touchstone was enforcement of the Voting Rights Act of 1965 (VRA). ${ }^{176}$ In terms of intermediate scrutiny, ensuring effective VRA enforcement is clearly a significant objective. As Secretary Ross explained, VRA enforcement requires an accurate determination of the citizenship voting age population (CVAP) in each state, since only citizens can vote in federal elections. ${ }^{177}$ In the abstract, posing a citizenship question on the short-form census is a reasonable way to obtain this information, consistent with the Secretary of Commerce's historic discretion.

The Supreme Court, in an opinion by Chief Justice John Roberts, upheld the district court's injunction against the citizenship question and its remand to the Commerce Department. The Chief Justice took a deferential substantive view of Secretary Ross's determination that asking a citizenship on the short-form census was a reasonable way to obtain citizenship information, but coupled that with a process-based finding that the Commerce Department's VRA rationale was "contrived." 178 Chief Justice Roberts noted that whether to add a citizenship question to the census was an "important" decision that required "genuine justifications." I79 In this respect, the Chief Justice found the Commerce Department's decision lacking.

Attacking the Commerce Department's substantive reasoning, the challengers to Secretary Ross's decision to add a citizenship question to the short-form census had argued that there are more accurate alternatives to the short-form census to accomplish the goal of obtaining citizenship data. Consider readily available administrative records. Secretary Ross's own memo announcing the inclusion of the citizenship question conceded that "administrative records could be more accurate than self-responses" on the short form. ${ }^{180}$ Self-reporting is simply not a good way to obtain accurate citizenship information. Secretary Ross conceded that, in responding to other Census Bureau requests for information, approximately one-third of noncitizen respondents incorrectly report that they are U.S. citizens. ${ }^{181}$ Under the circumstances, adding a citizenship question to the short-form census seems like throwing good money after bad.

176. Pub. L. No. 89-110, 79 Stat. 437 (codified as amended at 52 U.S.C. $\$ \$ 10101,10301-$ 14, 10501-08, 10701-02 (2012)); see also Memorandum from Wilbur Ross, supra note 3, at 1.

177. Memorandum from Wilbur Ross, supra note 3, at 1.

178. Dep'l of Commerce v. New York, 139 S. Ct. 2551, 2575 (2019).

179. Id.

180. Id. al 4: see also New York v. U.S. Dep't of Commerce, 35I I: Supp. 3d 502, 535 (S.D.N.Y. 2019).

181. See Memorandum from Wilbur Ross, supra note 3, at 4. 
Moreover, asking the citizenship question on the short-form census would have the adverse effect of "seriously jeopardiz[ing] the [distributive] accuracy of the census." 182 As noted above, experts agree that posing the question would deter participation by undocumented persons. It would thus skew the count against urban areas that are population centers for this cohort. ${ }^{183}$

Chief Justice Roberts rejected each of these concerns and ruled out rigorous means-ends scrutiny of the Commerce Department's decisions about what demographic information to seek on the short-form census. ${ }^{184}$ As Chief Justice Roberts put it, both using administrative records and asking about citizenship on the short-form census involved "tradeoffs between accuracy and completeness." 185 For Chief Justice Roberts, assessing the merits of these tradeoffs was a job for the Secretary of Commerce, not the courts. ${ }^{186}$ Justice Breyer, joined by Justices Ginsburg, Sotomayor, and Kagan, disagreed on the question of substantive deference, asserting that the Commerce Department's decision to add a citizenship question triggered issues of accuracy and completeness that rendered the decision arbitrary and capricious under the APA. ${ }^{187}$

But for Chief Justice Roberts, the process followed by Secretary Ross in linking the short-form census citizenship question to VRA enforcement nonetheless merited affirmance of the district court's injunction against asking the citizenship question-a sentiment shared by Justices Breyer, Ginsburg, Sotomayor, and Kagan. Roberts initially observed that the VRA rationale had "played an insignificant role in the decisionmaking process. ${ }^{p 188}$ Explaining this conclusion, Roberts stated that, according to the record, Secretary Ross had reversed the order of steps in agency decisions, by starting with a desired outcome and then maneuvering to achieve this result. As Roberts observed, Secretary Ross was "determined" to add a citizenship question "from the time he entered office," demanded that his staff "make it happen," and-when that was unavailing - collared "the Attorney General himself" to ask if the Department of Justice (DOJ) would cite VRA enforcement in requesting insertion of a citizenship question. ${ }^{189}$

All along the way, according to Chief Justice Roberts, the Commerce Department's process showed the "contrived" nature of its VRA

182. Hearing on H.R. 2661, supra note 162, at 43.

183. Id. at $43-44$.

184. Dep't of Commerce, 139 S. Ct. at 2569.

185. Id.

186. Id. at 2571.

187. Id. at 2587-92 (Breyer, J., concurring and dissenting).

188. Id. at 2574.

189. Dep't of Commerce, 139 S. Ct. at 2574. 
rationale. ${ }^{190}$ Ross's initial attempts to induce other agencies to request census-based citizenship data targeted the Department of Homeland Security and DOJ's Executive Office for Immigration Review, respectively, although neither agency has any role at all in VRA enforcement. ${ }^{191}$ When-after Secretary Ross's buttonholing of the Attorney General-the DOJ Civil Rights Division requested insertion of a citizenship question, its request was baldly instrumental, focusing on promoting Secretary Ross's desired outcome, not obtaining actual citizenship data. ${ }^{192}$ Indeed, the December 2017 DOJ request parroted the language and reasoning of Secretary Ross's staff and advisors. ${ }^{193}$ In its indifference to alternative ways to obtain data needed for VRA enforcement, the DOJ request diverged markedly from "typical" agency requests for assistance.

In isolation, each of these data points may have been insufficient to prompt doubts about the Commerce Department's good faith. Cabinet secretaries and other senior officials carry their policy predilections into office with them and work both with senior colleagues and subordinates to refine the legal basis for a policy decision. ${ }^{195}$ However, viewed in context, the Commerce Department's process illustrated a "disconnect" between its decision and the VRA rationale, indicating that the latter was "contrived" rather than "genuine." 196

Chief Justice Roberts appeared to reject rigorous means-ends scrutiny in the census case, instead opting for scrutiny of Secretary Ross's process in matching the VRA rationale with the decision to ask the citizenship question. However, Chief Justice Roberts' process-based approach paralleled means-ends scrutiny. ${ }^{197}$ Roberts' inquiry concerned whether Secretary Ross had acted in "bad faith" in seeking to link the citizenship question to VRA enforcement. ${ }^{198}$ A means-ends inquiry would have

190. Id. at 2575 .

191. Id.

192. Id

193. Id

194. Dep't of Commerce, $139 \mathrm{~S}$. Ct. at 2575.

195. Id. at 2574-75; see also In re Dep't of Commerce, 139 S. Ct. 16, 17 (2018) (Gorsuch, $\mathrm{J}$., concurring in part and dissenting in part) (" $\mid \mathrm{T}$ here's nothing unusual about a new cabinet secretary coming to office inclined to favor a different policy direction, soliciting support from other agencies to bolster his views, disagrecing with staff, or cutting through red lape.") (granting stay of district court's order to take Secretary Ross's deposition).

196. Dep't of Commerce, $139 \mathrm{~S}$. Ct. at $2575-76$.

197. (f. Richard Iallon, Constitutionally Forbidden l,egislative Intent, 130 HARV. I. Rl:V. 523. 545 (2016) (citing Elena Kagan. Private Speech. Public Purpose: The Role of Governmental Motive in First Amendment Doctrine, 63 U. CHI. L. Rl:v. 413, 443 (1996)) (discussing how tests used by courts serve as vehicles for revealing impermissible governmental intent).

198. Department of Commerce, $139 \mathrm{~S}$. Cl. at 2573-74. 
asked whether other alternative means were available to obtain citizenship data for achieving this goal. While Roberts did not ask this question directly in his opinion, he did note that the Census Bureau professionals had asked DOJ whether alternative means would address their concerns, and that DOJ had declined to explore other options besides the citizenship question. ${ }^{199}$ DOJ officials' indifference suggested that their real focus was not VRA enforcement. Instead, it was nakedly instrumental-providing cover for Secretary Ross's attempt to insert the citizenship question.

In this sense, Roberts' approach in the census case harmonized with means-ends scrutiny, which analyzes the relationship of means and ends to smoke out pretextual motivation. ${ }^{200}$ Given Roberts' ferreting out of pretext through weighing the government's process against its putative rationale, the Chief Justice's earlier discussion of deference to government choices about accuracy and completeness seems like dicta. Moreover, Chief Justice Roberts' willingness to look behind the government's putative rationale occurred in the context of a threshold rescission: the government's abrupt reversal of a concededly "important" policy choice. $^{281}$

\section{THE DACA AND TPS RESCISSIONS}

Finally, this Article addresses two immigration issues concerning the Trump Administration's efforts to rescind DACA and TPS. Here, too, agencies have a substantial measure of discretion. That is most evident with DACA, which entails deferred action-a form of relief rooted in the agency's convenience and enforcement priorities. $^{202}$ But TPS also undeniably entails discretion; indeed, Congress has insulated particular decisions about TPS from judicial review. ${ }^{203}$ That said, both are threshold measures: each determines whether a recipient can legally live and work in the United States. Rescinding each form of relief therefore should trigger robust means-ends scrutiny. However, in both cases, that scrutiny

199. Id. at 2575.

200. See Fallon, Constitutionally Forbidden Legislative Intent, supra note 197.

201. Dep't of Commerce, $139 \mathrm{~S}$. Ct. at 2575.

202. Arizona v. United States, 567 U.S. 387, 396 (2012) (explaining the importance of discretion in immigration enforcement); Reno v. Am.-Arab Anti-Discrimination Comm., 525 U.S. 471, 484 (1999) (noting that immigration enforcement units exercise discretion not to commence removal proceedings, which the Court termed "deferred action," based on a range of factors, including "humanitarian reasons or simply for [their] . . . own convenience"); Heckler v. Chaney, 470 U.S. 821, 831-32 (1985) (explaining why the Court held that most agency decisions not to start regulatory enforcement proceedings were unreviewable under the APA); see also Ronald M. Levin, Understanding Unreviewability in Administrative Law, 74 MINN. L. REV. 689, 715-17 (1990) (discussing pragmatic considerations in Chaney).

203. See 8 U.S.C. $\$ 1254 \mathrm{a}(\mathrm{b})(5)(\mathrm{A})(2012)$. 
focuses on the processes and modes of explanation that the agency has used. While each rescission fails the test, further effort could reverse that finding.

\section{A. The Constitutionalist Origins of the DACA Program}

The Department of Homeland Security (DHS) justified DACA initially as an exercise of prosecutorial discretion providing work authorization and a renewable reprieve from removal to foreign nationals who came to the United States as children and had no path to a legal status. ${ }^{204}$ As the Supreme Court observed in Heckler v. Chaney, ${ }^{205}$ a decision about whether to commence either a criminal prosecution or a regulatory proceeding is a product of an agency's "ordering of its priorities." ${ }^{206}$ In ranking its own priorities, an agency's knowledge of its own budget and personnel renders it "far better equipped" than the courts to assess the appropriateness of bringing a particular enforcement proceeding. ${ }^{207}$

That said, DACA - as well as the larger program for undocumented parents, DAPA - also sprang from an administrative constitutionalist

204. See Memorandum from Janet Napolitano, Sec'y, Dep't of Homeland Sec., to David V. Aguilar et al., Acting Comm'r, U.S. Customs \& Border Prot. (June 15, 2012), https://www.dhs.gov/xlibrary/assets/sI-exercising-prosecutorial-discretion-individuals-whocame-to-us-as-children.pdf [https://perma.cc/9N42-EALH]; see also Margulies, supra note 22, at 177 (2014) (analyzing DACA and finding it legal but conceding this was a close question). Compare Robert J. Delahunty \& John C. Yoo, Dream On: The Obama Administration's Nonenforcement of Immigration Laws, the DREAM Act, and the Take Care Clause, 91 TEX. $\mathrm{L}$. RI:V. 781,856 (2013) (asserting that DACA went beyond the scope of delegation), with SHOBA Sivaprasad Wadilia, Beyond Deportation: The Role OF Prosecutorial Discretion in IMMIGRATION CASES 54-59 (2015) (arguing that the ambit of discretion under INA included largescale programs such as DACA). The Justice Department's Office of Legal Counsel relied on a similar rationale in authorizing a larger program of immigration benefits, Deferred Action for Parents of Americans (I)PA). See Memorandum from Karl R. Thompson, Principal Deputy Assistant Attorney Gen., Office of Legal Counsel, to Donald J. Trump, President of the U.S. (Nov. 19, 2014), https://www.justice.gov/file/179206/download [htips://perma.cc/IIK2B-RWQV]. The Fifth Circuit subsequently ruled that DAPA exceeded Congress's delegation to the President. See Texas v. United States, 809 F.3d 134, 180 (5th Cir. 2015); cf. Josh Blackman, The Constitutionality of DAPA Part II: liaithfully lixecuting the Law. 19 Tlix. Riv. LAw \& POL. 213. 284 (2015) (arguing that DAPA exceeded presidential power). The author of this Article served as co-counsel for amici curiac in the Supreme Court phase of the Texas case, arguing that DAPA exceeded the agency's statutory authority. See Brief for Former Ilomeland Security, Justice, and State Department Officials as Amici Curiac Supporting Respondents at 2, United States v. Texas, 136 S. Ct. 2271 (2016) (No. 15-674).

205. 470 U.S. 821 (1985).

206. Id. at 832 .

207. Id 
vision and revealed that concept's normative tensions. ${ }^{208}$ DACA, with its solicitude for undocumented persons who came to the United States as children, echoed the notes of inclusion that the Supreme Court had first articulated in Plyler v. Doe, ${ }^{209}$ which barred states from denying public education to undocumented children. Finding that Texas's exclusionary legislation violated the Equal Protection Clause, the Court, in an opinion by Justice William Brennan, utilized a robust brand of means-ends scrutiny. ${ }^{210}$ Citing the U.S. Attorney General's acknowledgment that the federal government could not possibly deport all undocumented children within the foreseeable future, Justice Brennan found that Texas's aim of conserving resources was self-defeating. ${ }^{211}$ Texas's policy would not conserve resources in the long run for Texas or other jurisdictions, Justice Brennan opined. ${ }^{212}$ Rather, Texas's exclusion of undocumented children would impose social costs - what economists call negative externalities - by creating a cohort that lacked basic education and was therefore less able to contribute to the country. ${ }^{213}$

Prior to his presidency, then-senator Barack Obama invoked a vision closely resembling Plyler's in addressing the predicament of undocumented children. ${ }^{214}$ In his manifesto, The Audacity of Hope, Obama warned against withholding from undocumented personsespecially children-"the rights and opportunities that we take for

208. See generally Alina Das, Administrative Constitutionalism in Immigration Law, 98 B.U. L. REV. 485 (2018) (explaining why there is less overt recourse to constitutionalism among immigration officials compared with other agencies).

209. 457 U.S. 202 (1982).

210. Id. at 230 .

211. Id. at 226 .

212. Id. at 226,230 .

213. Recognizing the limits of the Court's holding, however, Justice Brennan acknowledged that Congress, which has primary responsibility for immigration policy and includes representatives of all states, retained the power under the Equal Protection Clause to enact such exclusive policies if it wished. Id. at 225 .

214. Supplementing this elaboration of Plyler, one can also view DACA as an extension of the president's authority to protect actual and intending Americans. See In re Neagle, 135 U.S. 1, 64 (1889) (describing an episode in which President Franklin Pierce protected the Hungarian refugee and intending American citizen Martin Koszta as support for presidential power to protect federal officials). See generally Henry P. Monaghan, The Protective Power of the Presidency, 93 COLUM. L. REV. 1 (1993) (arguing that there is essentially no presidential law-making power). Others have studied whether the President has constitutional power to decide how or if to enforce the law. Compare Zachary S. Price, Enforcement Discretion and Executive Duty, 67 VAND. L. REV. 671, 674-75 (2014) (suggesting constitutional limits on any such power), with Kate Andrias, The President's Enforcement Power, 88 N.Y.U. L. REv. 1031, 1035-36 (2013) (arguing for a broader conception). Many of these arguments also touch on which conception best promotes the rule of law. See David S. Rubenstein, Taking Care of the Rule of Law, 86 GEO. WASH. L. REV. $168,170-71$ (2018) (noting contradictions in arguments, practice, and rhetoric regarding the rule of law). 
granted." 215 Taking this exclusionary path, Obama grimly predicted, would create a "servant class in our midst" and spawn "inequality that . . . feeds racial strife." ${ }^{\text {"216 }}$ President Obama's 2012 op-ed heralding DACA's roll-out invoked this vision of equality even more forthrightly, framing DACA's beneficiaries as "young people who study in our schools, play in our neighborhoods, are friends with our kids, and pledge allegiance to the flag." ${ }^{217}$ Beneficiaries of DACA, President Obama declared, "are Americans in their heart and minds, in every single way but one: on paper."218 For President Obama, DACA would resolve that unjust anomaly.

\section{B. The Structural Counter to Broad-Based Deferred Action}

Yet, this assertion of equality had to compete with a structural constitutionalist retort. Challengers of DACA and the much larger program, DAPA, that President Obama sought to initiate in 2014, grounded their critique in the separation of powers. ${ }^{219}$ On this view, President Obama's programs exceeded the bounds of executive discretion. ${ }^{220}$ The Trump Administration initially relied in part on this competing constitutionalist paradigm and later invoked a related statutory argument citing doubts that Congress had delegated such broad-based discretion to the agency. ${ }^{221}$

The statutory argument started with the Supreme Court's nowfamiliar dictum that Congress does not customarily deposit "elephants in mouseholes" by delegating boundless discretion to the executive through ambiguous or generic statutory provisions. ${ }^{222}$ The Immigration and

215. Barack Obama, Tie Audacity of Hope 268 (2006).

216. Id.

217. See Barack Obama, A Nation of Laws and a Nation of Immigrants, TIME (June 17, 2012), http://ideas.time.com/2012/06/17/a-nation-of-laws-and-a-nation-of-immigrants/ |hitps://perma.cc/DBP6-UFUR|.

218. Id.

219. See Texas v. United States, 809 l:.3d 134, 180 (5th Cir. 2015); Blackman, supra note 204, at 217.

220. See Peter Margulics, The Boundaries of Fxecutive Discretion: Deferred Action, Unlawful Presence, and Immigration Law, 64 AM. U. L. RI:V. 1183, 1184 (2015).

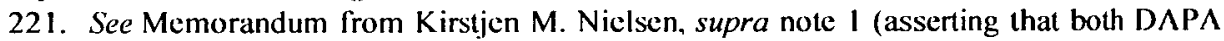
and $\mathrm{D} \Lambda \mathrm{C} \Lambda$ did not fit the Immigration and Nationality $\Lambda \mathrm{cl}$ 's (IN $\Lambda$ ) "comprehensive scheme" and that this mismatch with the statute raised "serious doubts about [DACA's] legality"); see also Memorandum from lilaine C. Duke, Acting Sec'y, U.S. Dep't of Ilomeland Sec., to James W. McCament et al., Acting Dir., U.S. Citizenship \& Immigration Servs. (Scpt. 5, 2017), https://www.dhs.gov/news/2017/09/05/memorandum-rescission-daca |https://perma.ce/GXK27WSJ | (citing statutory arguments and Attorney Gencral Jefr Sessions's claim that D $\Lambda C \wedge$ was an unconstitutional exercise of power by the executive branch). See generally Blackman, supra note 204 (framing the argument against I) $\wedge \mathrm{C} \wedge$ in both statutory and constitutional terms).

222. Whitman v. Am. Trucking Ass'ns, 531 U.S. 457, 468 (2001). 
Nationality Act (INA) is a carefully wrought structure that crafts specific categories of legal status to accommodate several potentially conflicting goals: family reunification, humanitarian values, economic prosperity, and law enforcement. For example, requiring that U.S. citizens be at least twenty-one years old to sponsor a parent for lawful permanent residence $^{223}$ addresses the so-called "anchor baby" problem by deterring unlawful entrants from obtaining immigration benefits through a postentry U.S.-citizen child. ${ }^{224}$ The age floor was a key element of the 1965 immigration amendments, which repealed national origin quotas that for decades had throttled legal immigration. ${ }^{225}$

Similarly, Congress has repeatedly warned that higher-than-specified levels of immigration could roil the job market, impairing the employment prospects and wage levels of U.S. citizens and lawful permanent residents. ${ }^{226}$ That deep-seated legislative anxiety impelled the 1986 Congress to provide for sanctions on employers hiring undocumented workers in a compromise that also provided immigrants with a major victory by legalizing a substantial number of undocumented persons living in the United States. ${ }^{227}$ In addition, Congress has restricted the ability of noncitizens without a legal status to obtain relief such as a

223. 8 U.S.C. $\S 1151($ b)(2)(A)(i) (2012); see also STEPHEN H. LEGOMSKY \& CHRISTINA M. RodrigueZ, IMMIGRATION AND REFUGEE LAW AND POLICY 251 (5th ed. 2009) (explaining the immediate relative category).

224. Hearings on S. 500 Before the Subcomm. on Immigration \& Naturalization of the $S$. Comm. on the Judiciary, 89th Cong. 20 (1965) (statement of Sen. Sam Ervin); see also id. at 230 31 (colloquy between Senators Ervin and Robert F. Kennedy on rationale for age floor on U.S. citizen sponsors); Margulies, supra note 220, at 1200-01 (discussing circumstances and results of this exchange).

225. See Gabriel J. Chin, The Civil Rights Revolution Comes to Immigration Law: A New Look at the Immigration and Nationality Act of 1965, 75 N.C. L. REV. 273, 279, 297--98 (1996) (describing the national origins quota system in place prior to the 1965 legislation).

226. H.R. REP. NO. 104-469, at 108 (1996) (finding that access to U.S. jobs was a "magnet" for unlawful migration).

227. See Immigration Reform and Control Act of 1986, Pub. L. No. 99-603, § 201, 100 Stat. 3359,3394 ; $c f$. S. REP. No. 99-132, at 16 (1985) (describing the 1986 legalization as a "one-time only' program"). Seeking to reassure Congress and other stakeholders that grants of deferred action, typically including a work permit, outside IRCA would be small in number, the Justice Department stated in 1987 that the "number of aliens authorized to accept employment [pursuant to deferred action outside IRCA] is quite small and the impact on the labor market is minimal." See Classes of Aliens Eligible, 52 Fed. Reg. 46,092, 46,092 (Dec. 4, 1987) (codified at 8 C.F.R. $\S 109$ ) (emphasis added). Indeed, officials claimed that the number of work authorizations was so small that it was "previously considered to be not worth recording." Id. at 46,093 (emphasis added). 
reprieve from removal and a work permit. ${ }^{228}$ Sweeping awards of deferred action risk eroding Congress's limits. ${ }^{229}$

While Congress did mention "deferred action" in the INA, statutory acknowledgment of this practice extends only to foreign nationals with a clear pathway to a legal status. ${ }^{230}$ Apart from situations in which deferred action is a "bridge" to a legal status, grants have been relatively rare, typically responding to hardships such as illness or old age. ${ }^{231}$ DAPA was to be a far larger program, and DACA also aids more immigrants than traditional hardship-based relief. ${ }^{232}$ The size of each program demonstrates its tensions with the statutory scheme. Virtually none of the actual or prospective recipients of either program could have used deferred action as a bridge to a legal status that would be available within a reasonable time. ${ }^{233}$

At the same time, DACA recipients can invoke compelling equities. First, as minors at the time of their entry into the United States, DACA recipients simply complied with their parents' instructions; they had no legal or practical capacity to veto their parents' plans. Second, as

228. See 8 U.S.C. $\$ 1229 c(a)(2)(A)$ (curbing practice of immigration officials who had granted extended voluntary departure (EVD) to individuals who did not fit into any established visa category by limiting EVD to 120 days).

229. Cf. Texas v. United States, 809 F.3d 134, 180 (5th Cir. 2015) (discussing basis for

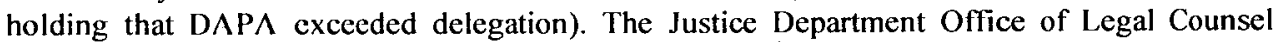
memorandum supporting DAPA recognized the program's impact. See Memorandum from Karl R. Thompson, supra note 204, at 31 (acknowledging that "the potential size of the program is large").

230. See, e.g., 8 U.S.C. $\$ 1227(\mathrm{~d})(1),(2)$ (providing for stay of removal and acknowledging availability of deferred action for applicants for visas created for victims of crime generally and victims of trafficking in particular, so that applicants do not undergo hardship of removal as they await processing of their applications); see also Texas, 809 F.3d at 184-85 (asserting that Family Fairness program granting deferred action to spouses and children of those legalized in 1986 was a "bridgell" to legal status, since those legalized were already authorized to sponsor spouses and children for permanent residence); $c f$. Adam B. Cox \& Cristina M. Rodríguez, The President and Immigration Law Redux, 125 YAL.E L.J. 104, 121 n.39 (2015) (arguing for broad presidential discretion but acknowledging with respect to lamily lairness program that, "those legalized ... would become eligible to petition for the admission of their spouses and children through the already existing immigration system" (emphasis added)).

231. Reno v. Am.-Arab Anti-Discrimination Comm., 525 U.S. 471, 484 n.8 (1999) (suggesting range of factors supporting grant of deferred action on a "case-by-case basis"); see also WADIIA, supra note 204, at 28 (outlining the need for prosecutorial discretion when making immigration-related decisions about noncitizens with severe medical illnesses).

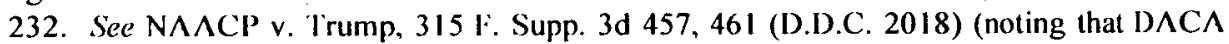
currently has over 800,000 recipients).

233. See Memorandum from Karl R. Thompson, supra note 204, at $29 \mathrm{n} .14$ (acknowledging that express statutory requirements stemming from law enforeement concerns would "likely not permit" prospective DAPA recipients to remain with their families "for the entire duration of the time until a visa is awarded" and indeed would often mandate protracted separations). 
President Obama observed, DACA recipients have from an early age developed social, educational, and cultural ties to the United States, ${ }^{234}$ but conspicuously lack an ongoing relationship with their countries of origin. For DACA recipients enrolled in the program since its inception in 2012, participation in the program has deepened this disjuncture between ties to the United States and lack of connection abroad. Compared with DAPA, deferred action under DACA thus more closely parallels immigration officials' venerable practice of granting removable persons relief from a range of hardships. ${ }^{255}$

This failure to address parallels between DACA and traditional uses of deferred action erodes the rescission's means-ends fit. Recall that DHS Secretary Nielsen asserted that rescinding DACA would address officials' "serious doubts" about the program's lawfulness. ${ }^{236}$ Secretary Nielsen's memorandum relied on the Fifth Circuit's decision in Texas $v$. United States ${ }^{237}$ holding that DAPA was not congruent with the INA's "comprehensive scheme." "238 However, Secretary Nielsen failed to adequately address distinctions between DAPA and DACA. ${ }^{239}$ A fuller explanation would have cemented the case for a rescission. ${ }^{240}$

234. See Memorandum from Janet Napolitano, supra note 204, at 2 (noting that many DACA recipients "have already contributed to our country in significant ways").

235. See WADHIA, supra note 204, at 57. But see Delahunty \& Yoo, supra note 204, at 794 95, 856 (asserting that DACA exceeded presidential authority).

236. Memorandum from Kirstjen M. Nielsen, supra note 1, at 2.

237. 809 F.3d 134 (5th Cir. 2015).

238. Memorandum from Kirstjen M. Nielsen, supra note 1, at 2; see Texas, 809 F.3d at 179 88.

239. See NAACP v. Trump, 315 F. Supp. 3d 457, 472 (D.D.C. 2018).

240. See id. The Ninth Circuit has taken a narrower view of DHS's options at this stage, finding that DHS had to show not merely that questions existed about DACA's legality, but that the program was clearly unlawful. See Regents of Univ. of Cal. v. U.S. Dep't of Homeland Sec., 908 F.3d 476, 505-10 (9th Cir. 2018) (finding an APA violation); id. at 518-20 (finding that DHS had to show DACA was clearly unlawful, also finding colorable equal protection violation). For the reasons detailed in the text, the Ninth Circuit's view unduly restricts DHS's authority under the INA and requires more than the Constitution compels. Along the same lines, the Ninth Circuit needlessly hamstrung DHS by holding that the APA required the agency to comprehensively state its rationale for rescission upon announcement of its decision, rather than permitting DHS to supplement its decision when courts sought clarification. But see id. at 505 (arguing that under the APA, DHS had to clearly state its reasons when announcing the rescission, and that DHS's pivot from a categorical judgment that DACA was unlawful to reliance on mere doubts about DACA's legality violated the principle articulated in the Supreme Court's decision in SEC v. Chenery Corp., 318 U.S. 80 (1943), that an agency can justify an action only by citing reasons that the agency considered before the action was taken). Under the view of the Constitution expressed here, an agency would have a reasonable opportunity to refine its rationale, and an initial judgment that a program was categorically unlawful would not undermine a subsequent finding that the program triggered serious legal doubts. 
Concededly, as with DAPA, DACA engendered legal questions because it announced "public policies of non-enforcement . . f for broad classes and categories of" otherwise removable foreign nationals. ${ }^{241}$ However, the Nielsen memorandum did not fully address arguments for DACA's legality, including its overlap with ongoing use of prosecutorial discretion to alleviate hardships such as youth, age, or disability. ${ }^{242}$ While DHS might well be able to make such a showing, it has thus far failed to do so. This failure would warrant halting the DACA rescission on equal protection grounds, although a more detailed future explanation could support the Administration's decision. ${ }^{243}$

\section{Rescinding Temporary Protected Status}

The courts should also analyze under intermediate scrutiny the Trump Administration's rescission of Temporary Protected Status (TPS) for longtime recipients from Haiti, El Salvador, Honduras, Nepal, Nicaragua, and Sudan. Generally, both an initial designation and a termination of TPS would be discretionary decisions, subject to either relaxed review or no review at all. ${ }^{244}$ However, the process of termination should be reviewable if the challenger raises constitutional claims. ${ }^{245}$ The Trump Administration's termination of TPS to the above-mentioned countries

241. Memorandum from Kirstjen M. Nielsen, supra note 1, at 2.

242. See WADHIA, supra note 204 , at 57.

243. Challengers to the DACA rescission have made out a prima facie case of discriminatory intent. As a backdrop, consider that $93 \%$ of DACA recipients are undocumented people of Hispanic origin, generally from Mexico or Central America. See Regents, 908 F.3d at 518. Candidate and now President Trump has showered insults on this group, referring to them as rapists, human traffickers, drug dealers, gang members, and terrorists. See, e.g., id. at 519-20; Michelle Mark, Trump Just Referred to One of His Most Infamous Comments: Calling Mexicans 'Rapists,' BUS. INSIDER (Apr. 5, 2018, 3:50 PM), https://www.businessinsider.com/trumpmexicans-rapists-remark-rcference-2018-4 [https://perma.cc/4XEM-6KRC]. The Supreme Court declined to view candidate and President Trump's statements about Muslims as triggering heightened scrutiny of the president's travel ban. See Trump v. Ilawaii, $138 \mathrm{~S}$. Cl. 2392, 2419 (2018). However, candidate and President Trump's statements on Central Americans and Mexicans are more pervasive and personal. See Regents, 908 F.3d at 520 (suggesting that DACA challengers provided "substantially greater evidence of discriminatory motivation"). Those statements meet the challengers' burden, if a court requires such a showing.

244. See 8 U.S.C. $\$ 1254 \mathrm{a}(\mathrm{b})(5)(\Lambda)(2012)$ (precluding judicial review of decisions regarding designation, extension, or termination of TPS).

245. See Saget v. Trump, 345 I:. Supp. 3d 287, 294-96 (I:D. N.Y. 2018); Saget, 375 I. Supp. $3 \mathrm{~d}$ at $341-55$ (granting a preliminary injunction against termination of TPS for I laitians); $\mathrm{N} \wedge \wedge \mathrm{CP}$ $v$. Dep t of Ilomeland Security, 364 F. Supp. 3d 568, 576-78 (1). Md. 2019)(finding that plaintiffs challenging revocation of TPS to Haitians had stated a plausible claim for relief). Acting due to injunctions against termination of TPS, the Department of llomeland Security has extended TPS for current recipients. See U.S. Dep't of I lomeland Security, Temporary Protected Status (2019), https://www.uscis.gov/humanitarian/temporary-protected-status |https://perma.cc/Y9N13-DJ49|. 
was not a particularized decision, but a categorical pivot away from TPS per se. That categorical pivot fails to fit means to ends.

TPS itself began, not as a statute, but as executive action. ${ }^{246}$ The protective power of the presidency has constitutional roots in the President's authority over foreign affairs. ${ }^{247}$ For over 150 years, presidents have protected intending Americans and those present in this country from hostile sovereigns. ${ }^{248}$ The period of American dominance after World War II saw greater use of this authority. ${ }^{249}$ Ultimately, Congress codified presidential power to protect individuals coming from abroad or already here from danger and hardship based on armed conflict, natural disasters, or other "extraordinary and temporary conditions" that impede foreign nationals from "returning . . . in safety" to their country of origin. ${ }^{250}$ Even after Congress enacted the TPS provisions, presidents have reserved to themselves constitutional power to take action that supplements statutory protections. ${ }^{251}$

The challengers to the Trump Administration's rescissions of TPS argue that the Administration has not complied with comprehensive statutory criteria in assessing the prospects for TPS recipients' safe return. In place of these comprehensive criteria, challengers allege that the current Administration has focused in an arbitrary and artificial way on whether the conditions that gave rise to the initial designation have persisted. ${ }^{252}$ This narrower analysis precludes adequate consideration of other factors, such as new natural disasters, that would make return unsafe. ${ }^{253}$ The Trump Administration's narrower approach erodes

246. See Margulies, supra note 22, at 107.

247. See In re Neagle, 135 U.S. 1, 63-64 (1890); Monaghan, supra note 214, at 3-5.

248. See Margulies, supra note 22 , at $112-13$.

249. See, e.g., id. at 127 (discussing the Bracero Program and its representation of the president's broad power).

250. See 8 U.S.C: $\$ 1254 a(b)(1)$ (2012).

251. See George H.W. Bush, Statement on Signing the Immigration Act of 1990, THE AM. Presidency Project (Nov. 29, 1990), http://www.presidency.ucsb.edu/ws/index.php?pid=19117 [https://perma.cc/HQ95-Q2F8] (asserting that the Executive might have constitutional power to protect otherwise deportable foreign nationals facing exigent situations in their country of origin); see also White House Office of the Press Sec'y, Presidential Memorandum - Deferred Enforced Departure for Liberians, WHITEHOUSE.GOv (Sept. 26, 2014), https://www.whitehouse.gov/thepress-office/2014/09/26/presidential-memorandum-deferred-enforced-departure-liberians [https://perma.cc/SLR3-NLXA] (announcing relief from removal for Liberians who previously had TPS and asserting "[his] constitutional authority to conduct the foreign relations of the United States").

252. Saget v. Trump, 345 F. Supp. 3d 287, 287, 294, 299 (E.D.N.Y. 2018).

253. Centro Presente v. Dep't of Homeland Sec., 332 F. Supp. 3d 393, 402-04 (D. Mass. 2018). 
statutory protections, according to the challengers, and amounts to a rewriting of the TPS provisions.

In addition to making this constitutional argument, the challengers also cite the collateral impact caused by the rescissions of TPS. ${ }^{255}$ In many cases, TPS recipients have been in the United States for well over a decade and in some cases, have resided in the United States for an even longer period of time. ${ }^{256}$ In the course of that stay, TPS recipients have developed ties to persons and entities in the United States. ${ }^{257}$ That process has been reciprocal. As a result, the collateral impact of a paradigm shift in TPS criteria equals or exceeds the impact of DACA's rescission.

The Trump Administration can point to a competing vision of administrative constitutionalism also centered on government responsibility. Generally, administration officials have argued that their determinations have been consistent with statutory criteria. However, one could also argue that the Trump Administration is seeking a sea change that will protect U.S. sovereignty from a slow-motion surrender to incursions from foreign nationals whose presence was supposed to be "temporary." As time passes, that presence seems more and more permanent. Arguably, the slide into permanence does violence to the statutory scheme and to U.S. sovereign prerogatives, which the Trump Administration wishes to reassert. The Administration's allusion in correspondence to an "America first" perspective on TPS reinforces this trope. ${ }^{258}$

While this justification for rescission invokes the federal government's responsibility, exercising that responsibility here is inconsistent with a categorical judgment to terminate TPS. Rather, the Due Process Clause requires that the Administration consider each TPS country designation, extension, and termination separately on its

254. Saget, 345 F. Supp. 3d at 299.

255. Id. See generally Amanda Baran et al., The Cost to Taxpayers, CDP, and Businesses of linding TPS, IMMIGRANT LISGAL. RISOURCE CTR. (Apr. 2017), https://www.ilrc.org/ sites/default/files/resources/2017-04-18_cconomic_contributions_by_salvadoran_honduran and_haitian_tps_holders.pdf. [https://perma.ce/3K8L_-GQRB] (summarizing some of the impact caused by the rescissions of TPS).

256. Robert Warren \& Donald Kerwin, A Statistical and Demographic Profile of the US Temporary Protected Status Populations from Lil Salvador, Honduras, and Ilaili, 5 JMIIS 577, 578 (2017), https://journals.sagepub.com/doi/pdi/10.1177/233150241700500302 |https:// perma.cc/ $/ 67 \Lambda-P \% G(G)$.

257. See The Consequences of Terminating Temporary Protected Status, CATH. LI:GNI. IMMIGR. NI:TWORK, INC. 3, hups://cliniclegal.org/sites/defaulufiles/resourees/The-Consequencesof-Terminating-Temporary-Protected-Status.pdf [hups://perma.cc/LID4K-9\%/BY].

258. See Ramos v. Nielsen, 336 f. Supp. 3d 1075, 1100 (N.I). Cal. 2018) (emphasis omitled). 
merits. ${ }^{259}$ The statute contemplates a look at whether TPS still serves the statutory criteria, including whether TPS recipients can return in safety. ${ }^{260}$ For example, regarding Haiti, DHS would consider whether safe return was impossible in light of post-designation conditions, including a devastating hurricane and a cholera epidemic. ${ }^{261}$

Instead, evidence submitted in each of the cases suggests that DHS, guided by the White House, first decided to terminate TPS for virtually all countries that have had it and then engaged in a narrow review that omitted the "return in safety" condition. ${ }^{262}$ That is not a narrowly tailored review of individual TPS designations; it is a wholesale pivot divorced from the merits and a "strong break with past practice."263 More importantly, it fails means-ends scrutiny. Under the approach taken here, DHS could revise its finding to include all current factors that imperil safe return, whether or not they existed at the time of the initial designation. That solution ensures due deliberation, but also provides sufficient space for administrative discretion in a democracy. ${ }^{26}$

\section{CONCLUSION}

If this Article has covered a lot of substantive ground, it is because the Trump Administration has endeavored to do the same as it rescinds programs, policies, and practices of previous administrations. Of course, the latter is not necessarily imprudent or unlawful. Indeed, competition about programs and priorities is the essence of democracy. Often, law will have little to say, and the courts no role to play. However, this Article

259. See Landon v. Plasencia, 459 U.S. 21, 32-33 (1982) (holding that due process applied in the case of a lawful permanent resident returning to United States). Equal protection is also relevant here to the extent that TPS recipients subject to a categorical termination of their status are-as a group - being treated differently than earlier TPS recipients.

260. See Saget, 345 F. Supp. 3d at 287, 292, 298, 299.

261. Id. at 299.

262. Ramos, 336 F. Supp. 3d at 1099 (finding that then-DHS Secretary Elaine Duke was informed by the White House of a "strategy" that apparently involved categorical judgment to terminate TPS). As noted with respect to Commerce Secretary Wilbur Ross's contacts on the census with other officials outside the Department of Commerce, senior officials can convey White House priorities to others in the administration. However, that communication should not include ordering officials to disregard statutory mandates. See supra Section III.B.

263. Ramos, 335 F. Supp. 3d at 1104 (quoting Degen Decl., Ex. 30).

264. If the challengers had to first make a prima facie showing of intent, they could cite to statements by President Trump. See Saget, 345 F. Supp. 3d at 303 (noting that upon learning 15,000 Haitians had obtained visas in 2017, Trump allegedly said "they all have AIDS") (quoting First Amended Complaint at 18, Saget v. Trump, 345 F. Supp. 3d 287 (E.D.N.Y. 2018) (No. 1:18cv-01599)). As with DACA, these statements are more pervasive than those in the travel ban case, and also address persons already living in the United States. $C f$. Trump v. Hawaii, 138 S. Ct. 2392, 2418 (2018) (cautioning about "delicate" task of parsing candidates' and officials' statements). 
argues that judicial review should be robust in assessing threshold rescissions.

Threshold measures include baseline criteria for institutional participation, as well as rules governing access to political representation and to the ability to live and work in the United States. Rescinding these measures upsets reliance interests. Because of the factfinding already invested in such rules and the legislative support they enjoy, courts should shift their familiar deferential stance to more exacting scrutiny of threshold rescissions' means-ends fit.

This Article's approach also aims to provide a normative facet to scholarly discussions of administrative constitutionalism. Scholars have recently pointed to compelling examples of agencies interpreting the Constitution outside of the courts to promote certain policies. ${ }^{265}$ Instances include expanding the definition of conscientious objection to the draft, curbing unfair state welfare policies, and promoting equal employment opportunity. ${ }^{266}$ In each case, officials, including future Justices Frankfurter and Stone in the conscientious objector example, went beyond what courts had mandated and implemented a distinctively administrative vision of the Constitution.

The administrative constitutionalism literature is still in an early stage of development and also has focused most intently on descriptions of the resourceful and dedicated public servants described above. It therefore has spent less time on normative issues. For example, scholars have not advanced criteria for ranking disparate administrative constitutionalist visions. That task is important, because one constitutionalist vision will often trigger contending visions. Those contending approaches will each cite the government's constitutional responsibilities, the limits of government power, and the rights of others. In addressing threshold rescissions proposed by the Trump Administration, this Article seeks to fill that gap.

In responding to threshold rescissions such as the Trump Administration's pivots on military transgender policy, the census, DACA, and TPS, the approach taken here subjects these moves to intermediate scrutiny. Courts should consider the means-ends fit of these shifts, ensuring that each is adequately tailored to a significant government objective. In the case of military transgender policy, tailoring would disaggregate the Department of Defense's rollback, which already correctly grandfathers in service members who acted in reliance on the Obama Administration's reforms. The longer stability requirement for accession would pass muster, but other components of the 2018

265. See, e.g. Kessler, supra note 17. at 1112.

266. See generally, e.g., Lec, supra note 21 (discussing this phenomenon in the context of equal employment opportunity); Tani, Administrative liqual Protection, supra note 17 (discussing this phenomenon in the context of wellare programs). 
Department of Defense policy would fall, including the bar on retention of service members who require accommodations for their expressed gender in bunking, bathroom use, and showering. Much of the 2018 policy, despite its drafting through a review process, does not effectively counter the common-sense arguments for inclusion made by Obama Administration Defense Secretary Ashton Carter, including Secretary Carter's argument that base rates are manageable and inclusion best allows the military to address the needs of transgender individuals who already serve.

On the census, DACA, and TPS, the approach taken here centers on the process for reaching and explaining a decision. As Chief Justice Roberts explained in the census case, the government's putative goal of enhancing VRA enforcement through asking a citizenship question was "contrived" in light of the process used to assert that rationale. ${ }^{267} \mathrm{On}$ DACA and TPS, DHS must provide fuller explanations: respectively addressing parallels between DACA and prior permissible uses of deferred action, and factors that interfere with TPS recipients' safe return, even when those factors were not present at the time of the initial TPS designation.

The approach taken here will not unduly burden incoming administrations. Often, as in the case of the 2018 Department of Defense policy's rule on accession and stability, means-ends scrutiny will uphold the change. In other cases, such as DACA and TPS, compliance will entail more comprehensive explanation. That burden is not unreasonable in a constitutional democracy. Perhaps the prospect of deeper public explanation will lead to the rethinking of some substantive measures. But that moderating influence is precisely what the Framers intended. Some administrations will deem it prudent to dial back their rhetoric to avoid promising more than they can deliver. That is an added virtue in a system that values continuity as well as discretion. Indeed, tempering rhetorical excesses may allow each side to more fully explore the other's vision of administrative constitutionalism. That, too, would match the Framers' design. 
